\title{
Integrated pest management for sustainable rice cultivation: a holistic approach
}

F. G. Horgan, University of Technology Sydney, Australia

\author{
1 Introduction \\ 2 Emerging rice production landscapes and 'crop health syndromes' \\ 3 Increasing rice production \\ 4 Increasing water productivity \\ 5 Reducing labour costs \\ 6 Increased availability and marketing of agrochemicals \\ 7 Pest management for rice: scientific approaches \\ 8 Knowledge of the rice production system \\ 9 Biocides, traps and barriers \\ 10 Transgenic and herbicide-resistant rice varieties \\ 11 Genetic approaches to resistance and tolerance \\ 12 Enhancing natural regulation \\ 13 Integrating management practices \\ 14 Education and extension \\ 15 Future trends and conclusion \\ 16 Where to look for further information \\ 17 References
}

\section{Introduction}

Integrated pest management (IPM) has been the dominant paradigm for crop protection since the 1960s. In theory, farmers practicing IPM will make decisions about pest management interventions that are economically justified, knowledge-based and that minimize risks to the environment and human health (Parsa et al., 2014). A key feature of IPM is an active monitoring of the crop for pest populations or damage that is weighed 
against some pre-established damage threshold above which farm profits would be negatively affected. Farmers are expected to balance the costs of intervention against the potential economic losses if no action were taken (Matteson, 2000). Although elegant in theory, it has been difficult to put IPM into practice on rice farms (Morse and Buhler 1997; Palis, 1998; Bandong et al., 2002) as farmers are pulled between opposing pest management paradigms and vested interests (Matteson, 2000; Matsuno et al., 2006; Spangenberg et al., 2015).

This chapter aims to critically examine IPM in rice. It assesses directions and advances in pest management science, and identifies opportunities and obstacles for IPM to form a basis for truly sustainable pest management. The chapter focuses on rice production from land preparation to rice grain storage, mainly in Asia.

\section{Emerging rice production landscapes and 'crop health syndromes'}

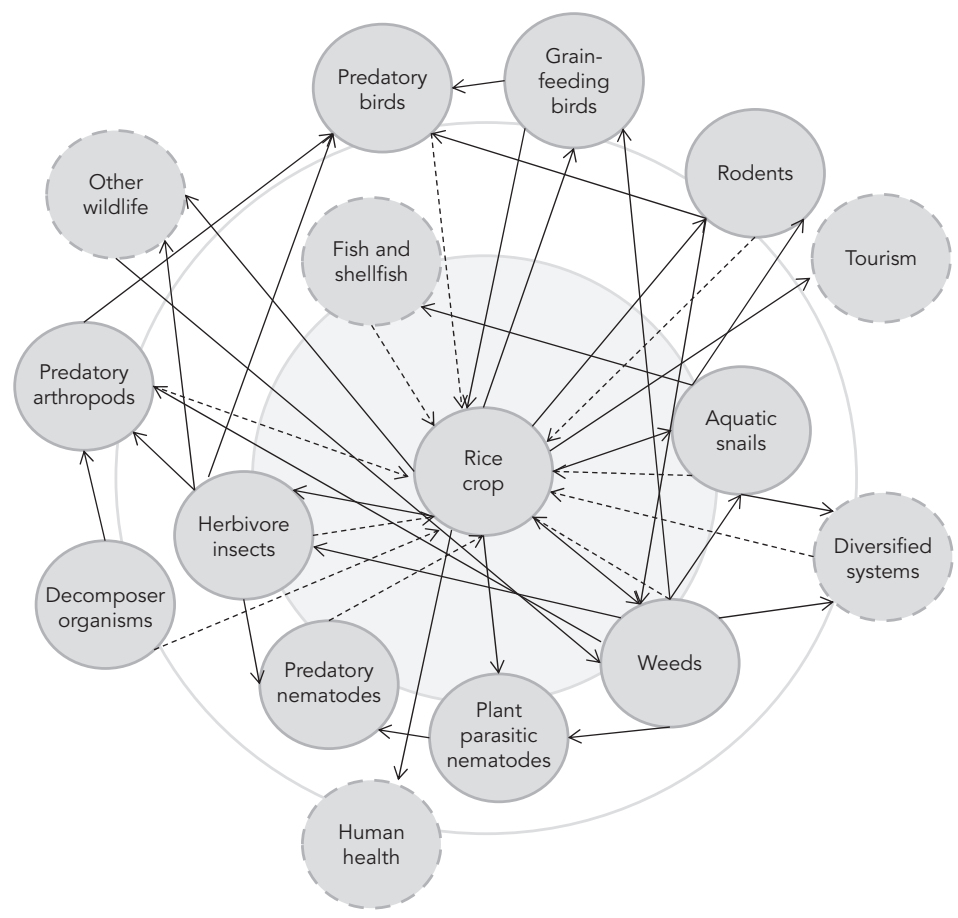

Figure 1 Relations between some components of the rice ecosystem. Components located closer to the rice crop (at the centre of the diagram) include permanent residents in the crop. Components located away from the centre are often occasional visitors to the crop that occur in the rice production landscape. Circles with dashed outlines represent other sectors that interact with rice production. Solid arrows indicate resource flows or benefits (in the direction of the arrow) to or from components. Dashed arrows are indirect benefits to the rice crop. 

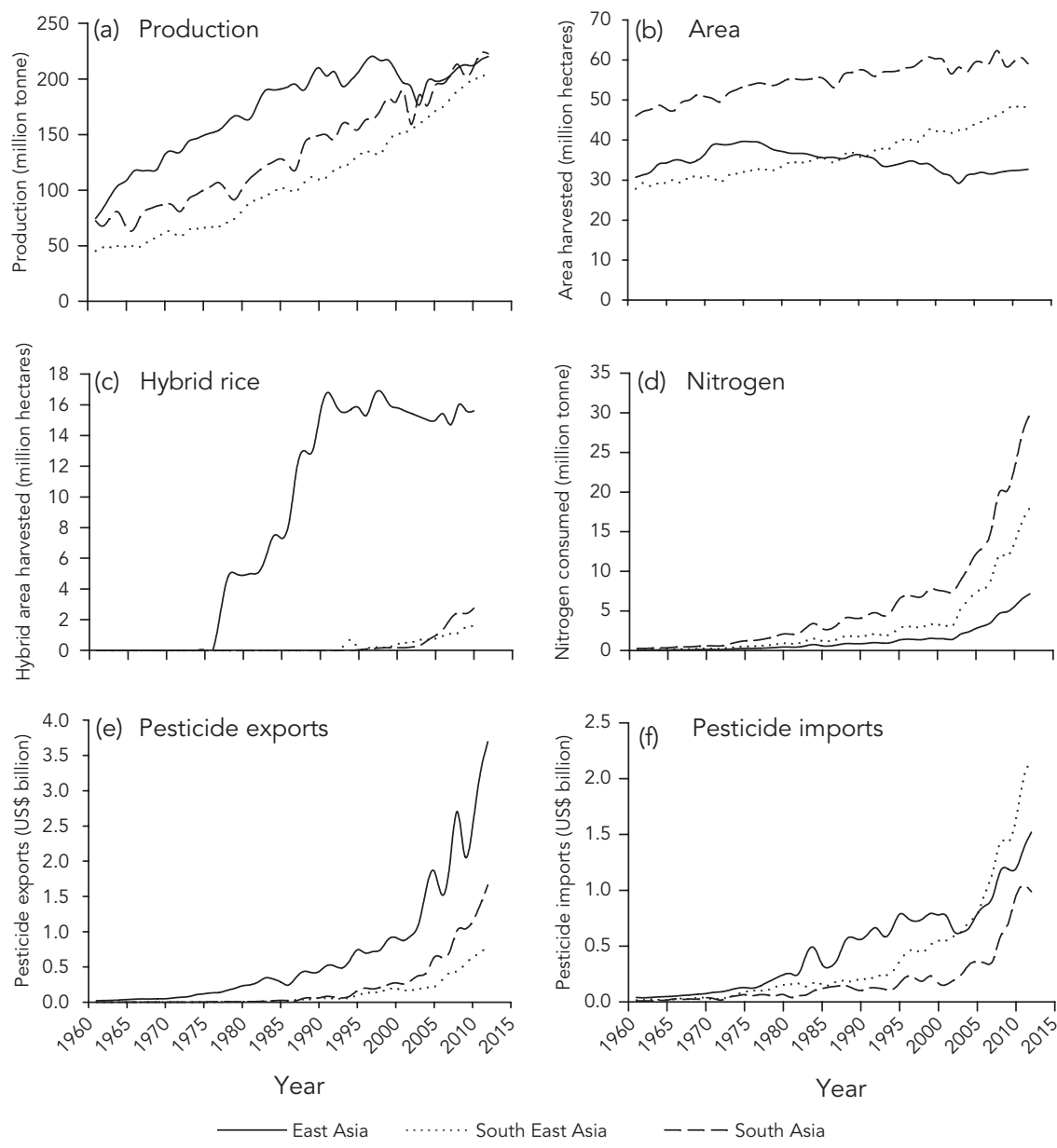

Figure 2 Trends in rice production and agricultural inputs in East (China, Japan and South Korea), South East (Cambodia, Indonesia, Malaysia, Myanmar, Philippines, Thailand and Vietnam) and South (Bangladesh, India, Nepal, Pakistan and Sri Lanka) Asia between 1961 and 2012. Graphs indicate trends in (a) rice production, (b) the area of rice harvested, (c) the area of hybrid rice planted (East = China; South East = Indonesia, Philippines and Vietnam; South = Bangladesh and India), (d) total nitrogen use, (e) total pesticide exports and ( $f$ ) total pesticide imports for each region. Graphs $a, b, d$, e and $f$ were drawn using open access data from FAO (2016). Graph c was redrawn from Horgan and Crisol (2013).

As farming practices evolve over time, associated pest problems will also change with them. It is useful therefore to approach pest management issues not as dealing with a series of individual problems, but in more holistic terms as approaching generalized 'crop health syndromes' (Savary et al., 2005; Reddy et al., 2011). This approach not only draws attention to production systems and associated management practices as drivers of pest problems, but also better reflects the several interrelations between different species 
components of rice ecosystems - some of which can become economically challenging (Moody and Drost, 1983; Pathak and Khan, 1994) (Fig. 1).

The idea of crop health syndromes also acknowledges trends in ecological succession acting on rice fields. For example, several herbivores, including insects, snails and rodents are associated with paddy field weeds (Drost and Moody, 1982; Tindall and Stout, 2003; Horgan et al., 2014a), sometimes facilitating the weeds by reducing shade from the rice canopy. Weeds may in turn lead to increased damage to rice from birds, as has been noted from recent studies in Africa (Rodenburg et al., 2014). The concept of crop health syndromes also recognizes that under different management systems, certain 'pests' may become beneficial 'allies' because of their predatory or herbivore roles, for example, apple snails (Pomacea spp.: Ampullariidae) may increase rice production costs by damaging young seedlings in flooded rice systems, but can play a major role in reducing weed biomass during later crop stages (Okuma et al., 1994).

Four of the major drivers of recent changes in rice production practices have been demands and policies for greater food security, demands for water conservation, increasing labour costs and an increasing availability of agrochemicals (Savary et al., 2005; Godfray et al., 2010; FAO, 2016; Fig. 2). Synergies in reducing greenhouse gas emissions or reducing energy consumption have helped favour certain changes of practice (Cai et al., 1997). Some examples of possible trade-offs and synergies for pest management are explained in the following sections.

\section{Increasing rice production}

Increasing rice production has involved (i) increasing land areas for agriculture and (ii) intensifying production per unit area by adopting high-yielding varieties (HYVs), applying higher amounts of fertilizer and reducing yield gaps.

\subsection{Increasing areas of production}

Many countries are faced with agricultural land shortages as farmland is progressively converted to make space for housing and industry. As land is reduced close to urban areas, natural areas and marginal lands face increasing pressures from expanding agricultural fronts (Balasubramanian et al., 2007; De Koninck et al., 2011; Cockfield et al., 2012; Grecchi et al., 2014; Laurance et al., 2014). New areas for rice production face distinct challenges compared to traditional rice-growing regions including damage from wildlife and weeds; for example, elephants (Elephas maximus L.), peafowl (Pavo cristatus L.) and wild boars (Sus scrofa L.) are often among the principal rice 'pests' indicated by farmers in the vicinity of wildlife sanctuaries in India and Sri Lanka. Such regions can become the focus of conflict between farmers and wildlife (Bandara and Tisdell, 2002; Santiapillai et al., 2010; Rana and Jain, 2013).

As rice production intensifies in expanding agricultural areas, and particularly where pesticide use is high, conflict between rice production and other economic sectors can arise. Such has been the case with aquaculture and rice farming in the Mekong Delta (Vietnam) (Pucher et al., 2013). Furthermore, despite clear advantages for adapting rice to climate change, the use of modern varieties with high tolerance to abiotic stresses such as submergence (Jagadish et al., 2012) also draws responsibilities for habitat management as marginal areas that were once a refuge for wildlife become more feasible 
for rice production. There is an urgent need for scientists and managers to develop sound strategies for coexistence of rice production, resource extraction activities (aquaculture and fishing) and wildlife conservation, particularly as biodiversity conservation is a major index of sustainable development.

\subsection{Increasing fertilizer use}

Increasing fertilizer use is the most likely pathway farmers will take to increase rice production (Stewart et al., 2005). Most plants and their herbivores are limited by nitrogen availability (Mattson, 1980); therefore, the addition of nitrogen to rice ecosystems affects a range of organisms including the rice plant, its weed competitors and their herbivores (Blackshaw et al., 2003; Hu et al., 2016).

Under high nitrogen conditions, rice plants grow faster, partition more biomass to shoots and grain, and gain tolerance to pests and diseases. However, they also become notably more attractive to pests and more susceptible to a variety of diseases (Horgan and Crisol, 2013; Horgan et al., 2016a; Hu et al., 2016). Field and laboratory studies have indicated higher levels of damage from insects, snails and weeds to rice produced under high nitrogen conditions (Eggum and Juliano, 1973; Ampong-Nyarko and Datta, 1993; Hu et al., 2016). The structure of weed communities (relative abundance and species richness) may also significantly change under high nitrogen conditions (Blackshaw et al., 2003). Furthermore, high levels of nitrogen have been shown to decrease the effectiveness of some anti-herbivore resistance genes in rice (Salim and Saxena, 1991; Vu et al., 2014; Horgan et al., 2016b), although this likely depends on the specific resistance mechanisms involved (Horgan et al., 2016c).

Rice plants under high nitrogen are predicted to better tolerate damage (can compensate for biomass loss) depending on the nature of the attacking herbivore or parasite (Horgan et al., 2016a; Prot et al., 1994). For example, yield losses to rice from certain insect herbivores can be avoided by treating affected plants with high nitrogen (Jiang and Cheng, 2003; Inthavong et al., 2004).

Under high nitrogen, weeds will also gain tolerance to their own herbivores and diseases (i.e. Suding et al., 2004). Furthermore, high nitrogen can lead to a greater carryover of weeds to successive cereal crops depending on the length and favourability of fallow periods for their germination and survival (i.e. Sexsmith and Pittman, 1963). The type of nitrogen fertilizer used may also reduce damage from certain pests. For example, ammonia-based nitrogen reduces root-knot nematode (Meloidogyne graminicola [Golden \& Birchfield]) infestation of rice (Patil et al., 2013) and causes significant mortality of apple snails (Stuart et al., 2014). Compared to chemical fertilizers, organic fertilizers are also associated with lower incidences of certain pests, particularly phloem-feeding insects (Hu et al., 2016).

\subsection{High-yielding varieties}

High-yielding rice varieties (HYVs) play an important role in attaining food security. However, HYVs may be more susceptible to pests and diseases than traditional varieties because of ecological trade-offs between yield (plant reproduction) and defences (resistance) (Brown, 2002); this has led to a large research investment in improving resistance in HYs (see Section 11). A major advantage of HYVs is the availability of certified seed, which reduces the incidence of weedy (red) rice, weeds and seed-borne diseases (Chin, 2001). However, HYVs are often indirectly affected by pests through associated management practices (Cheng, 2009; Horgan and Crisol, 2013). 
Farmers who adopt HYVs, particularly hybrid rice varieties, will often use higher amounts of fertilizer to meet the yield potential of the varieties (Cheng, 2009; Horgan and Crisol, 2013). Hybrid rice has been associated with higher incidences of several pests and diseases, including stem borers and planthoppers (Horgan and Crisol, 2013). Several hybrid rice varieties, particularly varieties with a wild abortive cytoplasmic male sterile (WA-CMS) parent, have noted susceptibility to the white-backed planthopper (Sogatella furcifera [Horvath]: Delphacidae: Homoptera) and green leafhoppers (Nephotettix spp.) (Cicadellidae: Homoptera) (Sogawa et al., 2003; Horgan et al., 2016a). This includes an estimated $40 \%$ of modern hybrid varieties and most Chinese-bred hybrids (Horgan and Crisol, 2013).

However, hybrid rice may be more tolerant of herbivore damage, which represents a major advantage for natural pest regulation in well-managed rice production systems, but also a potential drawback because it creates a reservoir for diseases, including insectvectored rice viruses (Horgan, 2012; Horgan et al., 2016a). Knowledge of the weaknesses of hybrid rice has led researchers to seek new sources of male sterility without associated planthopper susceptibility (Horgan and Crisol, 2013); however, faster growth rates and the nutrient demands of hybrids may continue to make these more attractive to herbivores (Price, 1991; Horgan et al 2016a).

Marketing of hybrids and other HYVs as part of a package with other inputs, including pesticides, could threaten their sustainability (Cheng, 2009; Horgan and Crisol, 2013). It is predicted that the high initial costs of purchasing hybrid and certified seeds and a general belief that hybrid rice is susceptible to insects and diseases will cause farmers to apply higher amounts of pesticides in an attempt to protect their investments (Pingali and Gerpacio, 1998). These pesticides are often supplied by the same agro-suppliers as the hybrid seed (orchestrated value chains: Hinterhuber, 2002). As will be seen in Section 6 of this chapter, high pesticide use can also result in increased pest and weed problems.

\subsection{Cropping intensity}

At landscape scales, issues around cropping systems, the synchrony of planting and the nature of the rice landscape in terms of crop diversity are important drivers of certain plant health syndromes. Increasing cropping intensity will increase the potential for insect herbivores to complete further generations and results in practical problems such as carryover of pests and weeds from one crop through stubble or fallow periods to the next crop (Holt et al., 1996; Azzam and Chancellor, 2002).

During dry fallows, where rice plants die, specialist herbivores such as the brown planthopper (Nilaparvata lugens [Stål]: Delphacidae: Homoptera) will disperse and populations decline or disappear (Holt et al., 1996). Dry fallows are also important opportunities for wild birds to consume dropped grain and prevent volunteer rice or weedy rice in succeeding crops (Stafford et al., 2010). In some regions, for example California (the United States), rice fields are flooded during non-productive winter fallows to conserve wild ducks; this also reduces weed abundance and biomass including the abundance of weedy rice and can contribute to nutrient cycling in the rice fields (Elphick and Oring, 1998; Van Groenigen et al., 2003).

In tropical regions with abundant water, a ratoon crop may develop during the fallow period. Ratooning rice can support pest populations between crops, particularly populations of plant-sucking homopterans that are attracted to new, fast-growing tillers (Fig. 3) - these may include important virus vectors such as leafhoppers. However, 


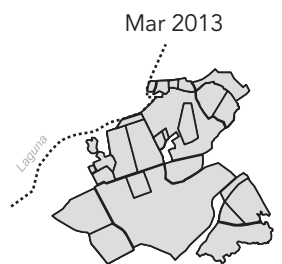

July 2013

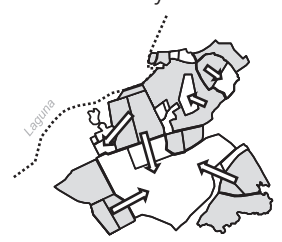

April 2013

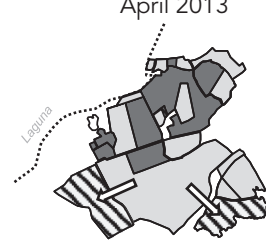

Sept 2013

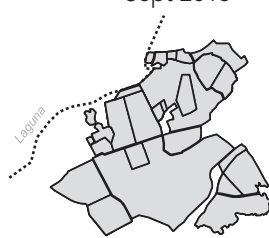

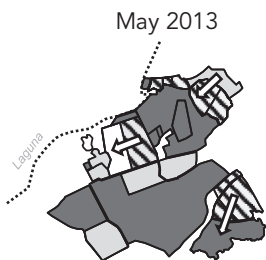

Oct 2013
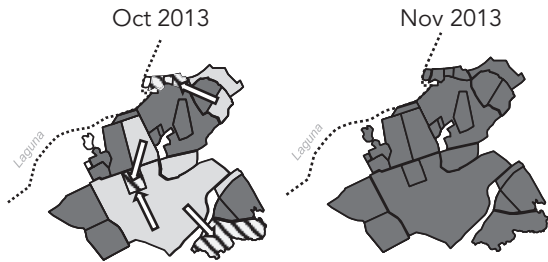

June 2013

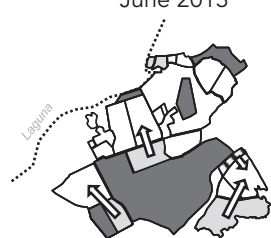

Nov 2013

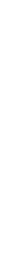

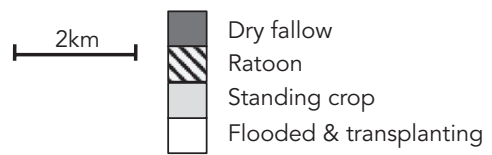

Figure 3 Cropping pattern at Pila, Laguna (Philippines), during 2013. Shaded polygons are rice fields adjacent to Laguna Lake (shoreline indicated by the dotted line). Asynchrony in the rice landscape creates refuges for herbivorous insects and their natural enemies. Arrows indicate predicted movements of insects from older crop stages to younger plants (transplanted seedlings and ratooning/active tillering plants). Poor synchrony is expected to maintain monophagous herbivores and their specialized natural enemies through the dry season crop (January to May) to the wet season crop (June to October). Dry conditions in November prevent ratooning and break the cycle of re-infestation.

ratooning rice also maintains predator and natural enemy populations that can reduce densities of pests in succeeding crops (Dela Cruz and Litsinger, 1988).

Synchronous planting is regarded as an important factor in reducing pest-related yield losses. Synchrony will have its greatest impact in areas with less intensive cropping and after extended fallow periods. Synchrony reduces the incidence of viral diseases such as tungro, and the incidence of stem borer and rodent damage in rice crops (Holt et al., 1998; Jacob et al., 2010). However, attaining wide-area synchrony of planting is often limited by water availability and the management of water supplies by local authorities. Rice fields that are planted late in an otherwise synchronous rice crop landscape are particularly vulnerable to leafhoppers and the viral diseases they transmit (Assam and Chancellor, 2002).

\section{Increasing water productivity}

Water productivity is defined as crop yield per unit of water consumed. Increasing water productivity in rainfed and irrigated systems involves (i) increasing the marketable yield of the crop for each unit of water transpired; (ii) reducing outflows; and (iii) increasing the effective use of rainfall, stored water and water of marginal quality. This is achieved by a 
combination of reduced land preparation time, adoption of intermittent or no flooding, and increased use or efficiency of fertilizers (Hafeez et al. 2007).

The duration and depth of flooding during rice production are key determinants of different crop health syndromes. For example, deep-water rice is rarely affected by pests other than stem borers (Catling, 1992). However, deep-water rice is severely hampered in regions where apple snails have been introduced (Horgan et al., 2014b). Because deep-water rice is produced in environmentally vulnerable areas, it constitutes an important habitat for wildlife including fish, amphibians, reptiles and birds (Catling, 1992). Options for pest control in such areas are therefore limited and pesticides have to be avoided.

Flooded rice in irrigated and rainfed production systems is vulnerable to a range of aquatic and semi-aquatic organisms as well as terrestrial insects and rodents that damage rice at different growth stages. However, flooding is recognized as important in controlling many weeds (Chauhan et al., 2012). In regions were Azolla (Azolla spp.: Salviniaceae) can still grow (these are often eliminated by apple snails) rice is further protected because the Azolla blocks light from the developing weeds (Biswas et al., 2005). With efforts to increase water productivity, practices such as intermittent flooding and direct seeding that reduce the amount of flooding result in a higher incidence of some weeds (Kürschner, 2010).

In upland and aerobic rice production systems, a range of distinct pests and diseases affect rice production. Insects such as termites (Isoptera), mole crickets (Gryllotalpidae) and beetle larvae (Scarabidae) attack rice roots, and parasitic nematodes are often so problematic that they restrict possibilities for successive rice crops (Litsinger et al., 1987; Prasad, 2011).

\section{Reducing labour costs}

Farmers are increasingly faced with the challenges of high labour costs and labour shortages. In many regions, increasing labour costs have incentivized farmers towards increased mechanization using either farmer-owned machinery or locally rented equipment. Furthermore, an increasing incidence of absentee landowners and migration towards urban centres often leads to consolidation of farms under a single management. Crop establishment and harvesting practices have been most affected by these recent trends (Savary et al., 2005; Timmer, 2005; Takahashi and Otsuka, 2009); but increasing labour costs will also reduce the feasibility of contracting labour for hand-weeding, hand collection of snails or spot pesticide applications.

Traditionally, flooded rice has been transplanted in much of Asia as seedlings of 15-30 days old. This labour-intensive process can effectively reduce damage from apple snails (Yanes-Figueroa et al., 2014) and weeds (Chauhan et al., 2012). A tendency towards labour saving has resulted in 'broadcasting' methods for crop establishment including wet and dry direct seeding and seedling broadcasting, each of which has associated benefits and trade-offs related to pest damage (Chauhan, 2012; Horgan et al., 2014c).

Wet direct seeding at high seeding rates reduces weed competition but is highly vulnerable to snail damage even under shallow flooding (ca. $1 \mathrm{~cm})$ (Horgan et al., 2014c; Horgan 2016). Dry seeding can conserve water use, but is more vulnerable to weeds (Chauhan, 2012); furthermore, both wet and dry direct seeding in many regions are affected by wader (wet seeding) and passerine birds (dry seeding) that directly consume either the broadcast seeds or the developing seedlings (Wilson et al., 1989; Lane et al., 1998). 
Seedling broadcasting and machine transplanting have potential to reduce labour costs while at the same time reducing pest problems (Horgan et al., 2014c); however, there is still a need to improve these techniques to enable transplanting of older seedlings, which are more robust and less affected by birds, insects and snails. Under proper seedbed management, some varieties can be transplanted as old as 40 DAS without yield loss (see Yanes Figueroa et al., 2014).

The choice of crop establishment method determines seedling densities and the number of seedlings per hill, both of which can be associated with different crop health syndromes. For example, a higher seedling density can reduce weed problems (Phuong et al., 2005) and has been noted to reduce the incidence of snail damage (Yanes-Figueroa et al., 2014). In a study from Thailand, Ishii-Eiteman and Power (1997) found green leafhoppers to colonize direct seeded fields more quickly than transplanted fields, but were more mobile in the transplanted fields, resulting in less aggregation of eggs and developing nymphs and more opportunities to transmit viruses between rice plants. Clearly, the spatial arrangement of rice seedlings will affect pest behaviours and their consequent damage potentials as well as influencing disease spread; however, few studies offer any empirical evidence to understand these processes in rice systems (see Section 8).

\section{Increased availability and marketing of agrochemicals}

In its August 2013 edition, the journal Science coined the term 'pesticide planet' to draw attention to the overwhelming use of pesticides in modern agriculture (Grullón, 2013). Agrochemical industries have thrived in recent years, chemical supply stores are now a common feature of rural communities, and prophylactic-calendar spray programmes are encouraged by agrochemical suppliers at field schools and open days throughout rice-growing regions (Sprangenberg et al., 2015). Pesticide imports in Asia have more than tripled $(3.4 \times)$ since the beginning of the millennium (Fig. 2) (FAO, 2016). However, evidence suggests that pesticides are an increasingly poor solution, if not a major underlying cause, for much of the pest-mediated yield losses in rice.

Figure 2 indicates massive increases in pesticide trade (imports and exports) in the rice producing nations of Asia over the last two decades. Several recent surveys of rice farmers in Asia also indicate a high level of pesticide use and little recourse to alternative pest control methods (Rejesus et al., 2012; Qiao et al., 2012; Abdollahzadeh et al., 2015). Paradoxically, the trend towards an increasing availability of chemical pesticides has not resulted in the expected lower pest and weed incidences, but to area-wide problems of resistant weeds (Powles and Shaner, 2001), sustained outbreaks of planthoppers and leaf folders (Crambidae) (Sprangenberg et al., 2015; Chintalapati et al., 2016), unstable management of snails (Horgan et al., 2014b) and worrisome consequences for environmental and human health (Pingali and Roger, 1995; Qiao et al., 2012), often without clear yield responses to chemical inputs (Pingali and Gerpacio, 1997; Sprangenberg et al., 2015).

\subsection{Insecticides}

Insect herbivores can quickly adapt to commonly used insecticides (Matsumura et al., 2008). In addition, several insecticides are associated with faster growth rates and 


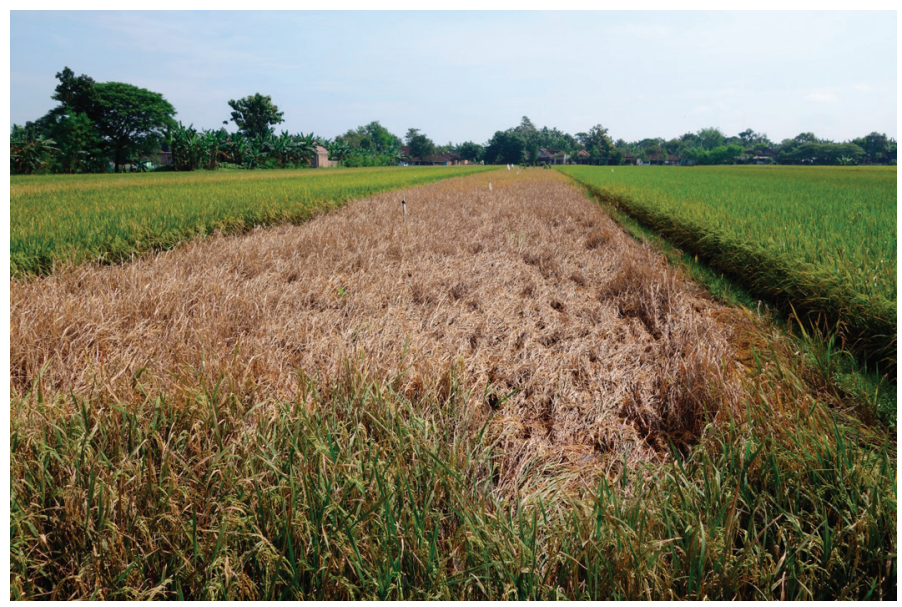

Figure 4 Varying degrees of damage to rice fields by the brown planthopper (Nilaparvata lugens) in Central Java (Indonesia) highlight the role of poor crop management in inducing outbreaks. Note that severe 'hopperburn' (plant death caused by planthoppers) is restricted to the central field in this picture from 2015. All fields in this photo were transplanted at the same time either with cv. Ciherang or the closely related cv. IR64, but farmers applied varying amounts and types of insecticide to their plots. Such well-defined spatial patterns to damage are indicative of insecticide-induced resurgence of herbivores.

increased reproduction in pest insects (Fig. 4) (Wang et al., 2005; Azzam et al., 2009; Chintalapati et al., 2016). To further add to the problem, the efficiency of natural enemies such as spiders and predatory wasps is reduced by insecticides either because they are directly killed by the chemicals or because their behaviours are altered (Kenmore et al., 1984; Tanaka et al., 2000; Horgan et al., 2017a). Increased reproduction and reduced mortality leads to exponential population growth rates in high-fecundity species such as planthoppers and leaf folders, a phenomenon known as 'resurgence' (Hardin et al., 1995). This can occur even on resistant rice varieties (Gallagher et al., 1994; Heinrichs, 1994). Over 100 published scientific reports have now described pesticide-induced resurgence in a range of rice pest insects including planthoppers, stem borers and leaf folders, as well as paddy-dwelling species of health concern such as mosquitoes (Culicidae). These studies have focused not only on a range of insecticides, but also on molluscicides, fungicides and herbicides that increase herbivore fitness (e.g. Grigarick et al., 1990; Wu et al., 2001; Wang et al., 2005; Assam et al., 2009; Xin et al., 2012; Horgan et al., 2014b).

In Indonesia, campaigns to reduce pesticide use through IPM and farmer field schools (FFS) and a government ban of several insecticides in 1986 resulted in a noted decline in outbreaks of the brown planthopper during the late 1980s and 1990s (Settle et al., 1996). Reduced pesticide use in several other Asian countries appears to have had similar effects (Pingali and Gerpacio, 1997). However, in recent years as pesticides have become cheaper and more readily available in Asia (Fig. 2), outbreaks of planthoppers have again increased in frequency and severity (Bottrell and Schoenly, 2012).

New insecticide products are made available to rice farmers on a regular basis. Although resistance to insecticides develops quickly, some products have not yet been associated 
with resurgence. However, insecticide products are rarely removed from markets even when they are known to cause resurgence, and farmers continue to use a variety of older products (Berg and Tam, 2012). The current situation of rapidly increasing insecticide use in Asia can be predicted to cause large-scale instability in insect pest populations and consequent pest outbreaks, and must be recognized as a major threat to rice production in the region.

\subsection{Herbicides}

Herbicide resistance has also been noted as a major constraint to rice farming in many parts of the world: hundreds of weed species are resistant to major classes of herbicide, and many species are resistant to multiple herbicide classes (Heap, 2014). Regions that have practiced direct seeding over several decades have been particularly affected. For example, weeds have become a major cause of yield decline for rice farmers in Sri Lanka who struggle to control grasses and sages using available products (Ranasinghe, 2003).

Management of weedy rice using Clearfield $₫$ and other herbicide-tolerant rice varieties has similarly succumbed to herbicide resistance: Clearfield $®$ rice harbours a mutation in the acetohydroxyacid synthase or acetolactate synthase enzyme rendering it tolerant to imidazolinone (IMI) herbicides (Sudianto et al., 2013). Clearfield $\circledast$ rice together with IMI herbicides were expected to reduce weedy rice problems in the Americas, Asia and Europe. Although resistance development was anticipated, the pace of development in tropical regions (particularly in South America) was more rapid than expected. Planting of 2-3 crops a year in warm regions and the absence of die-off of volunteer rice during winter has also facilitated the transfer of the acetohydroxyacid synthase or acetolactate synthase mutagen to weedy rice (Sudianto et al., 2013).

Increasing the use of herbicides due to water and labour-saving practices (handweeding had been common in Asian rice paddies), and the need to increase herbicide concentrations or applications to counter weed resistance, leads to higher herbicide concentrations in soils and water. Herbicides can be detrimental to wildlife (Takamura and Yasuno, 1986; Saka, 2010; Liu et al., 2011). Herbicide residues can also kill native vegetation and reduce the yields of successive grain crops, pastures or vegetable crops such that the use of selective herbicides prohibits certain crop rotations (Sudianto et al., 2013). Institutes and extension agencies that promote the adoption of herbicide-reliant rice production systems will need to consider how these systems can be sustained in an environmentally friendly manner as weeds continue to adapt to available chemicals.

\subsection{Molluscicides}

Molluscicide imports into Asia and other rice-growing regions have similarly increased in recent years (Adalla and Magsino, 2006). Snail damage to rice fields following the introduction of apple snails to several rice producing countries has been mainly treated using chemical molluscicides despite effective cultural control methods (Adalla and Magsino, 2006; Yanes-Figueroa et al., 2014). In fields treated with molluscicides in tropical Asia, surviving apple snails can grow rapidly, due to reduced intraspecific competition, representing a more serious threat to developing rice plants than untreated rice plots that have high-density snail populations but smaller individuals (Horgan, 2017). Farmer surveys in Ecuador have indicated that fields treated with molluscicides may also have a greater propensity for insect damage (Horgan et al., 2014b). 


\section{Pest management for rice: scientific approaches}

There are three main ingredients for successful IPM, these are:

i Knowledge of the rice production system, its component species (including the rice plant) and the nature of interactions between these species. It is also essential to understand how rice ecosystems, particularly their pest and weed populations, are regulated through negative feedback loops;

ii Tools to ensure that the outcomes of natural regulation favour yield and that ecological pathways (succession) towards damaging crop health syndromes are avoided. Such tools include traditional pest management practices such as flooding fields to prevent weeds, using traps or barriers to exclude rodents or snails, biological control and host plant resistance (HPR). Among these tools, pesticides must be carefully considered, as has been shown, since pesticides are often the underlying cause of pest-mediated damage and threaten environmental and human health;

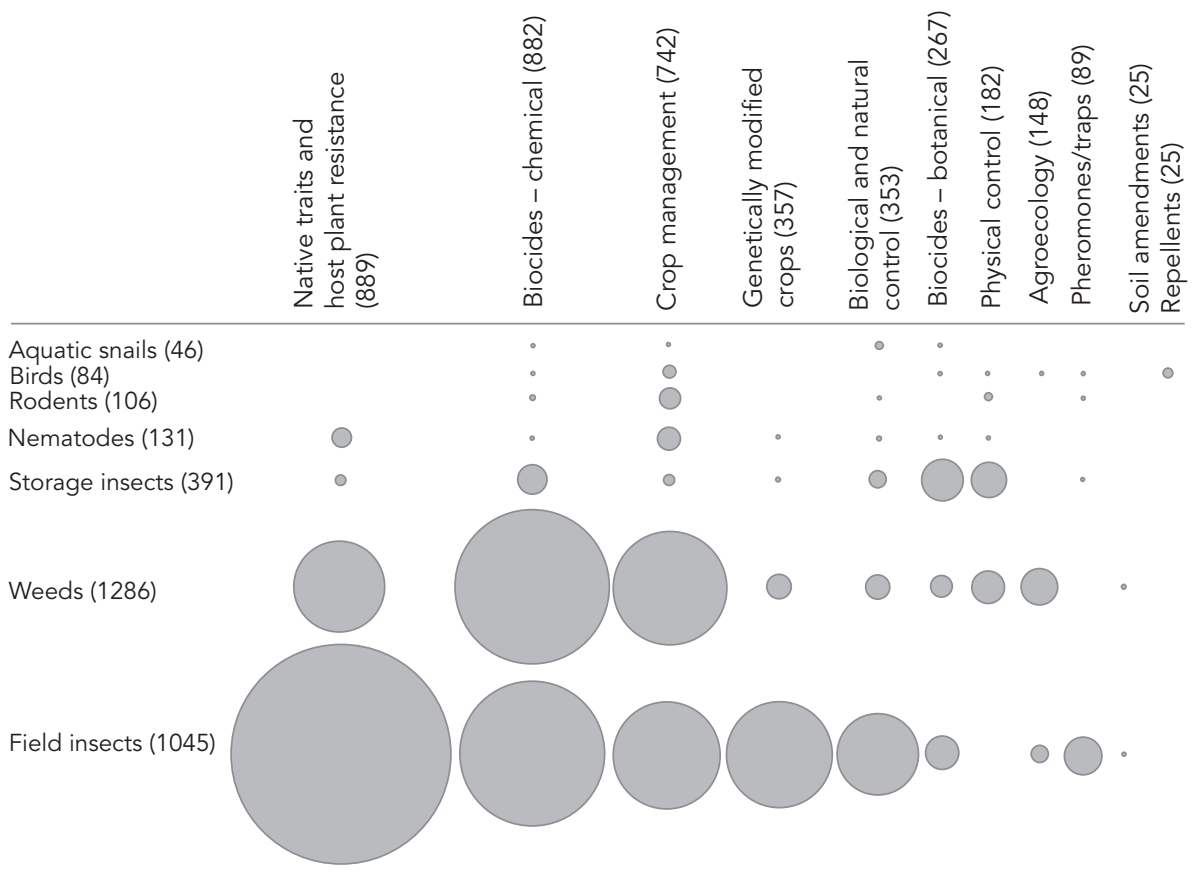

Figure 5 Focus of peer-reviewed scientific papers concerning rice pests and their management. The area of each circle indicates the number of papers with information relevant to the pest groups indicated in the side column and for broad topics indicated in the top row. The number of relevant records for each topic is indicated in parentheses. Note that a single paper may have information (records) relevant to different topics. Data are based on articles retrieved from Web of Science (1970 to June 2016) using 'rice' together with pest and weed genus names (based on key literature) as search terms. 


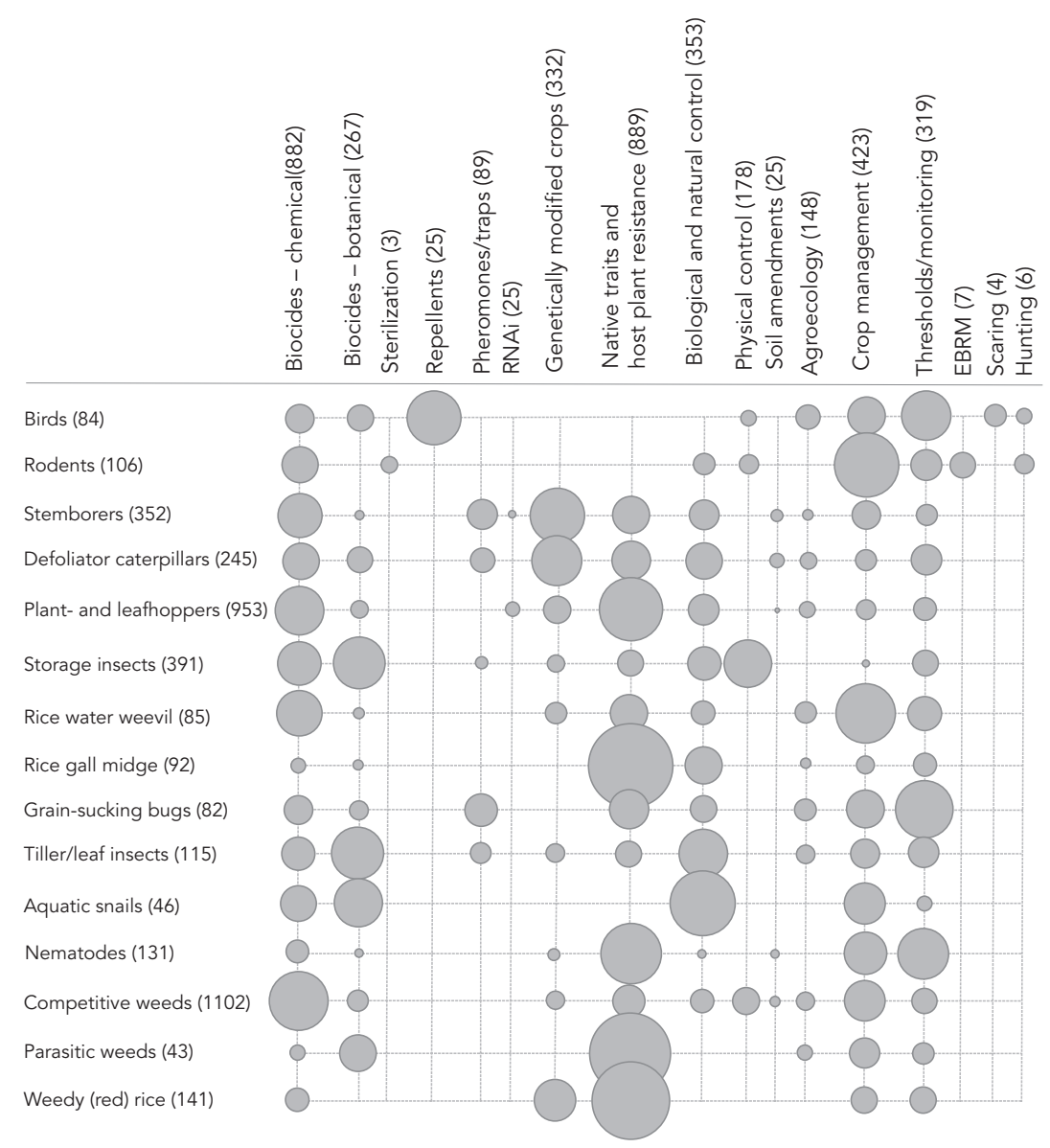

Figure 6 Focus of peer-reviewed scientific papers concerning rice pests and their management. The area of each circle indicates the proportion of papers focusing on the broad topics indicated in the top row for each pest group (indicated in the first column). The number of relevant records for each topic is indicated in parentheses. Data are from the same source as in Fig. 5. 'EBRM' is ecologically based rodent management.

iii Finally, IPM requires effective communication of knowledge and guidance of farmers towards best management practices. IPM is therefore as much about communication networks, didactic tools, effective extension and agricultural policy as it is about ecology or technology.

Figures 5 and 6 indicate the response by science to pest issues in rice. Peer-reviewed literature rarely addresses traditional (indigenous or farmer-derived) pest management practices, therefore the broad research areas indicated in the figures are not exhaustive of actual farmers' practices; they represent rather the areas of principal scientific interest. It should also be noted that the information in Fig. 5 and 6 represent accumulated scientific 
literature since 1970 and do not indicate current research emphases. This section focuses on how science has responded to the first two requirements for successful IPM? Issues around education and policy will be addressed in Sections 14 and 15.

\section{Knowledge of the rice production system}

Records of research into crop management and monitoring rank third in rice pest-related scientific literature in Fig. 5 (based on Web of Science retrievals, 1970-2016); however, in the last 20 years, this has represented only about $10 \%$ of studies in rice pest management. Early ecological research into rice production systems mainly focused on understanding the autecology of specific rice pests and their effects on rice production. However, despite several studies that have tried to assess damage or develop economic thresholds, there is still little understanding of yield losses due to rice pests: Most estimates present only ranges of damage or yield loss (e.g. 5-60\%). However, without knowledge of the frequencies and spatial extent of such losses, such information is of little value. Recent research has attempted to improve the situation by developing technologies to better detect pests including using remote sensing applications (Lamb and Brown, 2001; Yang et al., 2007). It will be necessary to continually update damage thresholds and estimated yield losses as climates and crop management practices change and because different rice varieties often have specific responses to pest attack (see Section 11). It is apparent therefore that, despite calls for changes in crop management, there has been little investment in the science needed to predict responses by pests and diseases. Without such knowledge, IPM will be severely limited.

\section{Biocides, traps and barriers}

\subsection{Chemical and botanical biocides}

According to Fig. 5 and 6, research into biocides has dominated pest management science for rice. Much of this research has included testing and promoting chemical control methods, particularly herbicides. A large body of information has also been generated to explain the mechanisms underlying pest (insect and weed) resistance to chemicals and resurgence in herbivores (see Sections 6.1 and 6.2).

In an attempt to reduce the negative effects of chemical pesticides, several researchers have focused on developing and evaluating botanical pesticides, particularly neem (Lim and Bottrell, 1994). A focus on botanical pesticides is prevalent in research on (i) storage pests, because of the need to avoid chemical contamination of foods (Isman, 2006); (ii) apple snails, because of a need to avoid chemical pesticides in water bodies (Horgan, 2017); and (iii) witchweed (Striga spp.: Orobanchaceae) - largely due to the discovery of strigolactones that can stimulate the germination of parasitic weeds and reduce their densities in the seed bank (Yoneyama et al., 2009; Dubey et al., 2010). Botanical biocides are regarded as safer than chemical poisons. However, they can also potentially cause resurgence (although there are still no records of such cases) and they are better applied under the same IPM guidelines as chemical biocides (Lim and Bottrell, 1994). 


\subsection{Pheromones}

Research into pheromones and baits was prominent in the 1990s, with research investments declining more recently. Synthetic pheromones are currently available for striped stem borer, Chilo suppressalis, ricebug, Leptocorisa chinensis Dallas and Indian meal moth, Plodia interpunctella (Hubner). These pheromones are rarely employed as sex disruptors but used more commonly in pest monitoring to help predict pest densities or to identify peaks in seasonal occurrence as a guide for management interventions (Kojima et al. 1996; Watanabe et al., 2009; Witzgall et al., 2010; Wilson et al., 2015).

\subsection{Light traps}

Light traps have featured in the management of certain insects, particularly planthoppers: Networks of light traps have operated throughout north-eastern China and Japan to detect waves of migrating planthoppers. During the northern hemisphere spring, brown and white-backed planthoppers migrate several thousand kilometres from South East Asia to the north east of Asia. Light traps have been used to determine the extent, direction and climatic conditions that generate these migrations and to act as an early warning system for rice farmers before planthoppers alight in their fields (Matsumura, 2001; Cheng, 2009). For example, rustic light traps have been operated in Vietnam as part of a successful 'escape strategy' whereby farmers determine rice planting dates based on the occurrence of peak planthopper densities in light traps (planting only after the peak has passed) (Bentley, 2009).

\subsection{Repellents}

Repellents have received considerable research attention as a method to control damage from grain-feeding birds to direct seeded rice, mainly in the United States. Repellents such as methyl anthranilate, pulegone and caffeine; and deterrents including coloured seed coatings have been shown to reduce the consumption of rice seed by birds (i.e. red-winged blackbird, Agelaius phoeniceus L: Icteridae) (Avery et al., 1996, 1999, 2005; Pawlina and Proulx, 1999). Simple ideas like seed coatings could help farmers to reap the benefits of birds in consuming dropped grain while at the same time avoiding losses during direct seeding.

\subsection{Barriers and traps}

Innovative physical barriers and traps are a prominent feature of ecologically based rodent and snail management in rice fields, and an essential feature in controlling storage pests including rodents and insects (Fig. 5 and 6). For example, hermetic storage bags reduce damage to stored rice from several storage pests (Guenha et al., 2014). Rustic storage facilities in developing countries are at higher risk from storage pests; here biocontrol agents, pheromone traps, botanical repellents and simple but cheap physical controls can considerably reduce losses from insects (Philips and Throne, 2009). In many cases, traditional exclusion methods including grain store designs and traditional construction methods may be effective against rat damage to stored rice (Sarangi et al., 2009) 


\section{Transgenic and herbicide-resistant rice varieties}

Following the development of Bt transgenic crops with resistance against chewing insects, transgenic resistance became the major focus of research into reducing stem borer and leaf folder damage to rice (31\% and $26 \%$ of all published studies, respectively) (Horgan 2012). Transgenic rice expressing lectins, protease inhibitors and venoms have also been considered to combat rice planthoppers and other rice pests (Murdock and Shade, 2002; Chen et al., 2012). More recently, research into RNAi technology has gained some attention for controlling planthoppers and stem borers (Fig. 6).

Transgenic and gene mutation approaches to developing varieties with novel traits have featured prominently in research into weed management: Glyphosate- and IMI-resistant rice has been developed to prevent damage to rice during herbicide applications and thereby better manage weeds (Sudianto et al., 2013). However, as mentioned above, the sustainability of herbicide-resistant varieties and caution about the transfer of transgenes or mutated genes to weedy rice, especially weedy hybrids has limited the application of these technologies (Chen et al., 2004; Sudianto et al., 2013 and see Section 6.2).

Transgenic rice varieties for pest management have not gained a foothold in rice production systems. This has been largely due to continuing debate over their potential long-term effects and difficulties in managing adaptation by target organisms, particularly in tropical regions where cropping is more intensive (Sudianto et al., 2013; Pu et al., 2014) and in developing nations where farms are small (usually $>2 \mathrm{ha}$ ) and where area-wide resistance management would be consequently difficult (Teetes, 1994).

\section{Genetic approaches to resistance and tolerance}

Native HPR has dominated research into rice herbivore management for decades. ('Native' refers to resistance derived from rice or its wild relatives.) Furthermore, the application of molecular and biotechnological tools to understanding insect-rice, nematode-rice and witchweed-rice interactions has represented $46 \%$ of all studies into rice pest management since 2000. 'Resistance' specifically describes a plant's ability to deter, kill or reduce the fitness of insects or nematodes. However, there is a broad range of possible interactions between pests and their rice host, each with potential benefits or trade-offs for pest management. For example, rice plants can vary in their tolerance to herbivore and parasite attack (Horgan, 2012). Tolerance is the ability of a plant to compensate for damage (Horgan, 2012; Horgan et al., 2016a). Some rice plants may also turn-on ineffective resistance pathways in response to pest attack (Agarrwal et al., 2014). Such responses may be detectable using modern molecular tools, but remain inconsequential in ecological terms.

Because the term HPR has a limited definition, this section focuses on what might be better called research into 'native traits and genes' - these are traits that can be acquired through conventional breeding programmes. Native traits have been the principal focus of research into the management of nematodes (39\% of all published nematode-related records), plant- and leafhoppers (42\%), witchweed (67\%) and rice gall midges (73\%) (Fig. 6). Native traits have also featured prominently in research into the management of stem borers (46\%) and defoliator caterpillars (41\%) as well as rice water weevil (18\%). The avoidance of genes involved in grain discolouration has been considered to reduce the impact of grain-sucking bugs (Gravois and Bernhardt, 2000). Furthermore, molecular 
approaches have been applied to understand shattering and dormancy as traits leading to the invasiveness of weedy rice and to understand gene flow between cultivated and weedy rice (62\%). The search for allelopathic rice varieties and molecular approaches to improving rice competition with weeds, although not as prominent as research into other native traits, was topical between 2000 and 2010 . More recently, allelopathy as a function of rhizosphere bacteria has gained increasing attention (Lin et al., 2010).

Using native traits as tools for herbivore, nematode, witchweed and disease management has been approached in two principal ways: (i) the screening and elimination of susceptible rice lines during breeding programmes and (ii) the inclusion of major resistance genes into breeding lines and modern varieties.

\subsection{Screening}

Screening involves challenging potential rice breeding lines with important pests or diseases and recording the resulting damage. Screening can be conducted under field conditions, but is more usually conducted in greenhouses or laboratories. Such screening studies are often effective, particularly where they identify varieties that are novel for a target pest population (normally indicated by low damage compared to susceptible rice varieties). A novel variety might include a variety that is phenologically distinct from the main varieties in the region of interest (the target region) and therefore represents a barrier to dispersal and to successful attack by the target pest (Horgan, 2012). Routine screening of this type appears to be successful in reducing damage from rice planthoppers in some parts of Asia (Widawski et al., 1998; Horgan and Crisol, 2013).

Good screening methods are essential to deliver improved varieties to farmers. What is noteworthy here is that excessive yield losses are avoided in the resulting varieties because rice phenotypes with high susceptibility and/or low tolerance are simply excluded from breeding programmes. Unfortunately, routine screening using methods such as standard seedling seedbox tests (SSST) is often unreliable, is difficult to interpret and gives variable results according to conditions in the screening facilities (Fujita et al., 2013). Furthermore, to ensure that screening is useful, test organisms should be derived from recently established herbivore colonies or parasite strains. For example, researchers at the Centro Internacional de Agricultura Tropical (CIAT - Colombia) renew their planthopper, Sogatodes oryzicola (Muir), colonies every 2 years when screening for resistance to Rice Hoja Blanca Virus. However, test colonies and strains at many institutes are often deliberately maintained for several years as research 'biotypes' or 'pathotypes' to facilitate laboratory-based breeding programmes (Fujita et al., 2013). Whereas this may hold advantages for gene discovery, it is not recommended for screening studies.

\subsection{Incorporating major resistance genes in rice}

To develop resistant rice varieties, scientists can identify loci containing resistance genes and, using molecular tools such as marker-assisted selection (MAS), ensure that these genes are maintained through the breeding pipeline (Rispail et al., 2010; Chen et al., 2012; Fujita et al.; 2013). The advantage of this approach has been to permit the repeated backcrossing of susceptible HYvs with resistance donors while ensuring that the genes of interest are not eliminated from advanced lines. Increasingly, resistance donors include near-isogenic lines with single or 'pyramided' (including two or more resistance genes in the same line) resistance genes (Fujita et al., 2013). 
One major problem associated with this approach to pest management is that resistance (unlike tolerance) exerts selection pressure on the target organisms. Already the development of virulent pest populations has become a serious issue for anti-herbivore resistance: For example, in a recent study, researchers from South and South East Asia evaluated the effectiveness of several donor varieties with known resistance genes against the brown planthopper. Their results indicated that most genes were now ineffective, but that traditional varieties and landraces containing two or more resistance genes remained largely effective (Horgan et al., 2015). This supports the idea that pyramiding resistance genes can improve the durability of anti-herbivore resistance (Fujita et al., 2013). However, ecological theory predicts a limit to pyramiding defence genes without appreciably affecting yield (Brown, 2002). As yet, no published study has tested this hypothesis in the context of resistance against herbivores in rice.

In the face of growing research interest in native traits for pest management, some probing questions need to be asked: For example, with such a large investment in research on insect HPR, why has insecticide use increased so dramatically in Asia in recent years? Such a trend suggests that, if deployed, resistance will simply reduce the profitability of rice farms unless farmers also reduce their pesticide inputs (Pingali and Gerpacio, 1998; Widawsky et al., 1998). Clearly there is a need to better insert HPR and other native traits into IPM strategies; however, there has been a distinct lack of research in this area. In particular, issues around the deployment of resistant varieties need to be more fully examined (Fujita et al., 2013; Horgan et al., 2015). Here, researchers may gain from the rich research into deployment of transgenic crops (Gould, 1998) to better direct deployment of native resistance. However, this will require an improved understanding of rice field ecology as well as understanding the socio-economic realities of rice farmers.

\section{Enhancing natural regulation}

Investments in ecological research for pest management in rice have lagged behind research investments in molecular breeding, biotechnological and biocide approaches (Fig. 5 and 6). Furthermore, among reports from research into the natural pest management of insects indicated in Fig. 5 and 6 are several recent studies on the effects of transgenic crops on specific predatory species from the rice community as well as studies on the mechanisms underlying insecticide-induced resurgence of pest insects (see Section 6.1). Also, much of the research indicated under 'crop management' for weeds in Fig. 5 and 6 has only compared flooding or direct seeding against 'new' herbicide treatments. Studies that clearly focus on ecological approaches to the management of pests and weeds by identifying or testing specific ecologically based interventions are comparatively rare.

\subsection{Biological control}

Biological control agents have been tested for their effects in reducing infestations by herbivorous insects, nematodes and snails in rice. Classical biological control is rarely contemplated even after the introduction of noxious weeds and damaging insects to new regions, although studies do continue to identify suitable biological control agents against introduced aquatic weeds that also occur in rice (Culliney, 2005). Classical biological 
control works at regional levels and is not specific to rice fields, although rice farmers are identified as beneficiaries of such programmes.

Inundative biological control has been investigated for the control of rice field insects, nematodes and storage pests. These studies have focused on the development of rearing and application methods for Trichogramma spp. (Trichogrammatidae) to control stem borers (Ko et al., 2014); the use of Metarhizium spp. (Clavicipitaceae) and Beauveria spp. (Cordycipitaceae) to control several insect and nematode pests (Loc and Chi, 2005; Meyling and Eilenberg, 2007); and the use of bacteria (i.e. Pseudomonas fluorescens [Flügge] Migula and Bacillus spp.) to control insects, nematodes and rice diseases (Commare et al., 2002; Padgham and Sikora, 2007). Among the advantages of using fungal and bacterial biocontrol agents are the ease with which they can be reared and the facility with which they can be applied in the field (Meyling and Eilenberg, 2007). However, they do exert selection pressure for pest adaptation if used in excess.

Biocontrol of insects and snails using ducks and fish has gained recent attention as part of integrated farming systems. Ducks in particular have been shown to reduce snail densities. Farmers in many regions where apple snails have been introduced will invite duck herders to direct their ducks through rice fields (Teo, 2001). Successful management of insects and snails by fish has been more difficult to achieve and can have associated problems. For example, the common carp, Cyprinus carpio L, clearly reduces snail densities, but carp is an invasive threat in some regions (Ip et al., 2014). In general, the effectiveness of biological control has been difficult to determine. Nevertheless, key areas for research have been largely overlooked, including the discovery and use of entomopathogenic viruses or snail-killing nematodes in rice fields.

\subsection{Natural pest management}

The need to maintain natural enemies in rice fields and allow these to build up populations has been well recognized for decades. A current paradigm for natural enemy dynamics is that generalist predators will consume decomposers at the time of crop establishment and during seedling stages, but later move to consume rice pests as these begin to colonize the young rice plants (Settle et al., 1996). For this reason, it is strongly advised not to spray rice fields with insecticides during the first 40 days after transplanting (Kenmore et al., 1984). The success of this heuristic has been borne out by several studies, and most recently by a convincing study from China (Gurr et al., 2016).

Massive applications of pesticides in recent years (see Section 6) have increased fears that natural enemy numbers have become depleted in Asian rice fields. Therefore, several strategies have been devised to restore natural enemies, increase their efficiency and also improve the resilience of rice ecosystems against perturbations - including resilience against climate change (Gurr, 2009; Gurr et al., 2016; Westphal et al., 2015; Horgan et al., 2016d). For example, in a comprehensive study, Kiritani (1999) indicated that most predators and parasitoids in Japanese rice fields were likely to increase the number of generations they achieved by 2 or 3 under average mean monthly temperature increases of $2^{\circ} \mathrm{C}$, whereas most rice pests would only increase their generations by one. This suggests that under increasing temperatures, numerical responses to pest densities by many natural enemies would be enhanced, thereby improving pest regulation. However, spiders are expected to achieve the lowest increases in generations (ca. 0.6 per year) under increasing temperatures (Kiritani 1999), potentially decreasing their effectivity. By creating suitable 


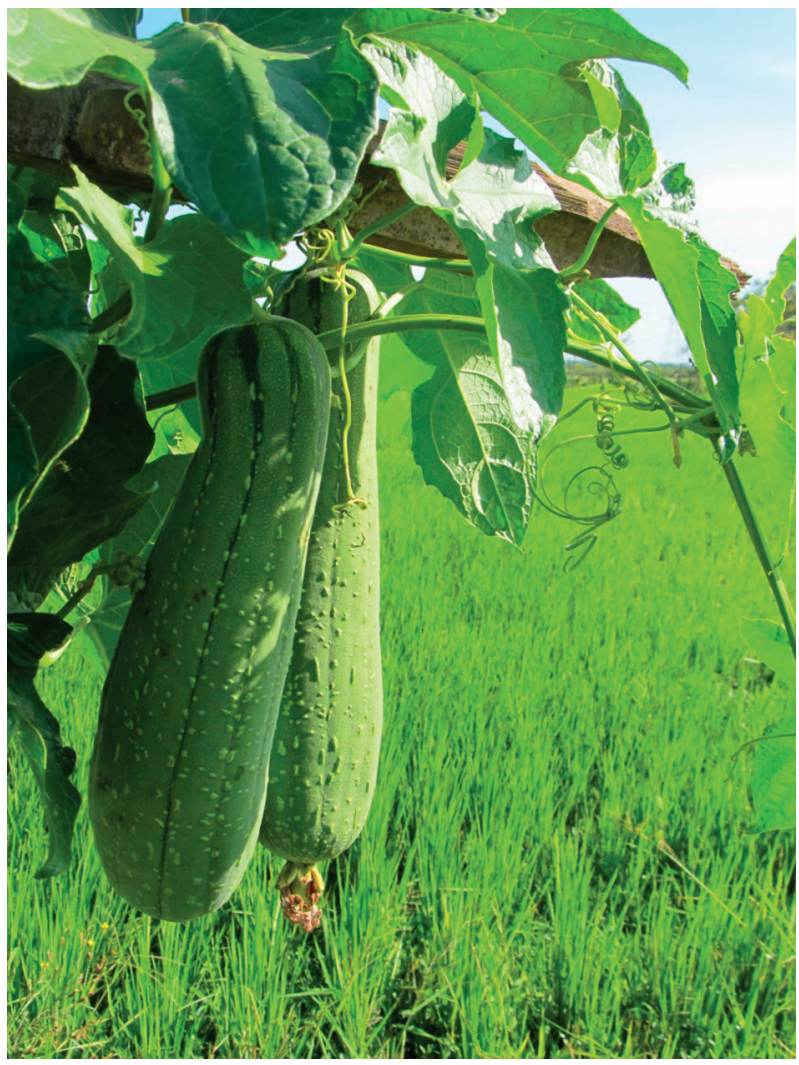

Figure 7 Ecological engineering: Luffa (Luffa spp.: Cucurbitaceae) grown on rice bunds is attractive to parasitoids and predatory wasps that feed from its large yellow flowers. Wild birds, including predatory species, use bamboo supports to scan the rice fields for insects and apple snails (see Horgan et al., 2017b). By growing plants of function such as these, farmers can increase the abundance and diversity of the natural enemies of stem borers and leaf folders in their rice fields and, at the same time, increase productivity on their farms.

habitat for predators such as spiders, any potential negative effects of global warming on natural pest regulation could be avoided (Kiritani, 1999).

Strategies that create adequate habitat for natural enemies can be included under the broad title of 'agro-ecology'; however, recently the terms 'ecological intensification' (Gurr et al., 2016) and 'ecological engineering' (Gurr, 2009; Horgan et al., 2016d) have gained prominence. Ecological intensification implies increasing the per unit production of farms through the application of ecological principles while at the same time 'sparing' natural areas for biodiversity conservation. Though the concept is often used in terms of simple intensification practices, ecological intensification is more correctly associated with diversification of crop production in time and space (Bommarco et al., 2013; Gurr et al., 2016). Unfortunately, evidence suggests that intensifying agricultural lands for food and fibre production is unlikely to lead to sparing of natural areas, particularly in developing 
nations (Phelps et al., 2013). Ecological engineering is a related concept, but stresses the design of habitat based on species interactions and feedback mechanisms that are highly predictable. Ecological engineering goes further by proposing the development of production systems with benefits for both man and nature (Gurr, 2009; Horgan et al., 2016d), in effect 'sharing' spaces with native biodiversity.

Rice systems that diversify habitat by including plants of known function to enhance the services provided by key species in the rice ecosystem (other than direct food production) are examples of ecological engineering. Ecological engineering research in Asia has mainly focused on creating flower strips and vegetable patches as a source of alternative foods and refuge for the natural enemies of planthoppers and stem borers (Fig. 7). Recent reports have indicated that such systems can successfully increase rice yields, reduce pest damage, reduce or eliminate pesticide inputs, increase the biodiversity and function of predators including predatory birds, and increase farm profits and food production by using the space available on rice bunds (levees) or in specially constructed earthen platforms to grow vegetables (Westphal et al., 2015; Gurr et al., 2016; Horgan et al. 2016d, 2017a,b).

Despite such apparent success, there is still a need for further research into ecological engineering and other diversified farming systems. This includes research to avoid problems due to pests such as rats that might benefit from planted bunds or the close cultivation of other crops (Horgan et al., 2016d). Nevertheless, the continual adaptation of such diversified systems by including elements such as fish or ducks, incorporating soil amendments such as biochar or silicon (both of which reduce pest damage [Huang et al., 2015]) and planting high-yielding but pest-resistant rice varieties has enormous potential for achieving both sustainability and food security targets.

\section{Integrating management practices}

The review of pest management research and techniques presented in Sections 7 through 12 indicates a general partitioning of potential management approaches and research efforts. Recent innovations in pest management certainly hold promise in reducing pest damage to rice. However, it is clear that more research attention is required to bring the different 'technologies' together into functioning and sustainable rice production systems. For example, research into ecological engineering and biocontrol has rarely incorporated innovations in HPR into research platforms, and HPR research often ends with the 'resistant variety' or 'resistance locus', without considering deployment and management of pest adaptation, or rice field ecology. Future research might benefit from more successfully integrating such diverse components of pest management.

\section{Education and extension}

A recent study by Parsa et al. (2014) examined reasons for the poor adoption of IPM in different crops through a survey of 163 IPM professionals and practitioners from around the world. The survey identified 51 obstacles to IPM adoption in developing countries. The top 10 reasons for non-adoption included knowledge-related issues (lack of training, little technical support, limited availability of information), structural issues (lack of government policy and support, limited funding), implementation issues (prohibitive costs, limited 
access to inputs, difficult implementation) and issues related to competing interests (powerful influence of the pesticide industry).

Recent surveys and cognitive studies from Asia suggest that rice farmers are driven to use pesticides, particularly insecticides, based on exaggerated expectations of yield loss (risk aversion) (Palis, 1998; Bandong et al., 2002; Pingali, 2001). A lack of adequate extension support and of basic ecological knowledge means that farmers often initiate pesticide applications when they observe 'insects' or damage, but generally cannot distinguish pests from beneficial organisms and cannot project from their field observations to realistic damage potentials (Bandong et al., 2002). Furthermore, farmers communicate regularly with pesticide vendors that promote prophylactic pesticide applications or calendar sprays without any pest monitoring; herbicides, molluscicides and fungicides are generally applied following calendar applications, an approach that is increasingly common with insecticides (Robinson et al., 2007).

One approach to overcome a lack of farmer knowledge about pests and beneficial organisms has been to directly train farmers through informal courses and campaigns. For example, Indonesia's National Integrated Pest Management Program and the FFS of the Food and Agriculture Organization of the United Nations (FAO) were successful in reducing insecticide use in the 1990s (Matteson, 2000; Thorburn, 2015). The 'three reductions, three gains' (3R3G) campaign promoted through the Ministry of Agriculture and Rural Development in Vietnam after 2000 was similarly successful in reducing pesticide inputs (Huan et al., 2008). The campaign promoted a reduction in seeding rates, fertilizers and pesticides to improve rice profitability (adding that environmental and farmer health would also gain). Campaigns such as these have benefited by exploiting existing extension systems as well as expanding to mass media such as radio and TV (Huan et al., 2008; Bentley, 2009; Westphal et al., 2015). However, education campaigns are expensive and difficult to sustain and evidence suggests that adoption of IPM declines rapidly after education campaigns have ended (Rejesus et al., 2012).

Rice knowledge banks, made available through specialist websites, could sustain the knowledge of farmers and government extension technicians. Knowledge banks are digital information repositories with simplified retrieval interfaces to help users understand rice crop management, pest problems and, occasionally, beneficial organisms. Several national and international institutes maintain such websites. In some cases specialised knowledge 'apps' have been made available to farmers through smartphones (i.e., Rice Knowledge Bank Bangladesh Rice Research Institute), and several research groups plan to develop interactive 'apps' whereby farmers can receive diagnostic support from remote specialists after answering key questions or uploading images of potential pests encountered in their fields (personal communications with app developers at the National University of Singapore).

As an extension of their knowledge bank, the CABI Plantwise programme has developed a system of plant clinics, including mobile clinics, for rice farmers in Thailand, where farmers receive advice in managing potential pest problems (Leach and Hobbs, 2013). Such systems are designed to support sustainable rice production and promote IPM among rice farmers; however, they are limited by the availability of trained staff and financial support, and if used incorrectly, could encourage unnecessary pesticide applications where information is not followed through with adequate management advice or where knowledge pathways are discontinuous. Government support for such remote extension initiatives will be important to promote their continuity; but it will be essential to ensure healthy partnerships between researchers, funders and infrastructure suppliers during the development and implementation of such schemes if the knowledge they provide is to be used correctly. 


\section{Future trends and conclusion}

As discussed throughout this chapter, it is apparent that rice crop management practices are changing in response to key drivers. These changes are often promoted as beneficial to the economic and environmental sustainability of the rice sector. However, although economic advantages can be assessed through traditional cost-benefit analyses using monetary or production indicators, assessing the environmental impact of change has been more difficult. One area of difficulty has been to develop balanced indicators of environmental quality that weigh advantages in one area (e.g. water productivity) against costs in another (e.g. biodiversity loss and water contamination).

Systems approaches can help define and evaluate pest problems associated with different rice production systems and their component practices, as well as determining the best solutions to the problems from among a range of alternatives (Teng and Savary, 1992). As an essential economic activity, it is convenient to examine rice production using value chain analysis (VCA), which attempts to examine in detail the value-added steps in production and marketing, where values are not only monetary but also social (Bolwig et al., 2010). As part of a VCA, farmers' decisions around agronomy and pest management, the costs of management and the potential losses from pests should be addressed. However, only in rare cases can VCA guide researchers towards mediation of environmental impacts (exceptions being where there is a direct cost to production or a yield advantage or penalty due to the environmental consequences of some management intervention).

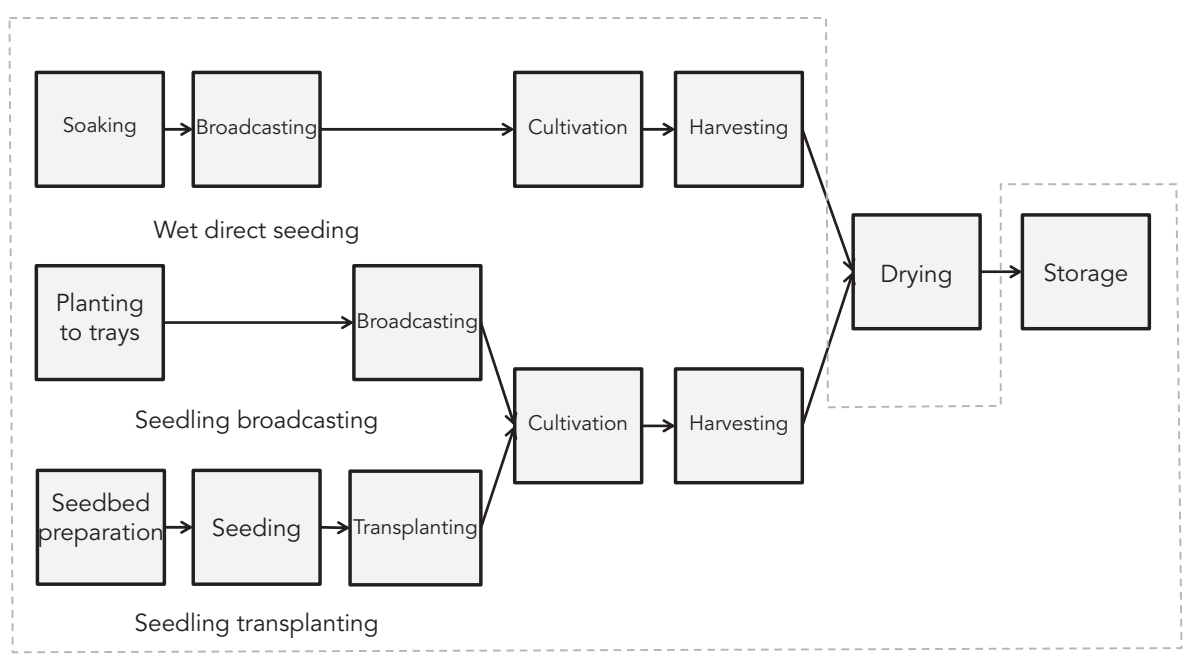

Figure 8 Life cycle of rice and system boundary (identified inside the dashed box) for topics in this chapter. As an example, the diagram indicates three crop establishment methods for comparison using LCA, highlighting the differences in cultivation and harvesting methods after direct seeding and seedling broadcasting or transplanting. Each stage in the life cycle can be assessed against a series of impact indicators designed to safeguard the environment and human health. 
To factor in environmental concerns and manage the environmental impacts of rice production, a range of techniques around life cycle assessments (LCAs) has been developed (i.e. Blengini and Busto, 2009). Although these have initially focused heavily on mitigating greenhouse gas emissions and the energy costs of grain production, there have been recent calls to include assessment of risks to biodiversity and consequently to the ecosystem services provided by animal and plant communities in production landscapes (Teillard et al., 2016).

LCA involves defining the boundaries of the study system, conducting a detailed compilation of all environmental inputs and outputs at each stage of the system and quantifying the relative importance of all impacts using specific indicators (such as water use, eutrophication potential, energy requirements, biodiversity loss and global warming potential) (Fig. 8) (Blengini and Busto, 2009). Whereas VCA focuses mainly on economic and social sustainability, LCA focuses predominantly on issues of environmental sustainability. A natural blending of VCA and LCA might address more fully the essential aspects of sustainable development of the rice sector. However, in general, linking LCA and VCA requires some environmental bookkeeping for which realistic and recognizable cost/value estimates cannot be easily derived.

Without adequate development of LCA techniques that allow a thorough assessment of different rice production systems and practices, researchers might adopt the precautionary principle as they strive for healthy rice ecosystems. Healthy rice ecosystems will produce sufficient quantities of safe food to be economically sustainable, but also function to maintain biodiversity, manage floodwaters, improve rural aesthetics and support cultural identity. The concept recognizes that farmers are themselves affected by environmental degradation and that pesticides are a major health and production challenge (Pingali and Roger, 1995; Horgan et al., 2016d). IPM could gain renewed vigour if inserted into such an integrated framework and assessed using evolving system analytical tools. The major challenge for sustainable futures is to simultaneously respond to a range of global challenges including climate change, food insecurity, increasing poverty and environmental degradation. With such complicated demands on future rice production systems, adequate frameworks based on integrated assessment tools can greatly support policy and direct holistic research approaches.

\section{Where to look for further information}

Global problems require global solutions. Researchers will need to forge links with colleagues from different regions, disciplines and core interests to better grasp the complexity of issues and determine the best solutions to sustainably manage rice systems both as production areas and as a healthy habitat for humans and wildlife. In recent years, a number of researchers have developed agro-ecological approaches to pest management including ecological engineering. In many cases the fruits of their research are only now coming to light. Researchers at AfricaRice and at CIRADAgricultural Research for Development have tested plants of function in West Africa and in upland rice areas of Madagascar. Charles Sturt University in Australia (Graham Centre for Agricultural Innovation, School of Agricultural and Wine Sciences) has been a leader in ecological engineering in rice and now has a satellite laboratory in China. Also in Australia, researchers at the Centre for Compassionate Conservation, University of 
Technology Sydney, are conducting research in ecological engineering in rice and wildlifefriendly rice farming in Asia and Australia. Researchers at the University of Connecticut (Department of Ecology and Evolutionary Biology) lead efforts in wildlife-friendly rice in the United States.

For information on developing herbivore- and disease-resistant rice using molecular tools, readers can contact researchers at the Faculties of Agriculture of Kyushu University and Saga University in Japan and researchers from the Rice Department of the Government of Thailand. These researchers have greatly contributed to the development of near-isogenic rice lines with several herbivore resistance genes. Researchers at the College of Life Sciences of Wuhan University, China, have also identified and pyramided genes for several resistance traits in modern rice lines and investigated the mechanisms underlying resistance. Researchers at AfricaRice in collaboration with Makerere University (College of Agricultural and Life Sciences) have similarly gained much recent knowledge in control of witchweed using HPR.

Several researchers are developing environmental accounting techniques to improve the sustainability of rice farming. Researchers at the Institute of Physical Geography and Landscape Ecology at Leibniz University in Hannover (Germany) and at the Department of Community Ecology of the Helmholtz-Centre for Environmental Research in Halle (Germany) have developed sustainability indicators for rice ecosystems in Asia. CABI's Plantwise programme has offered a new direction for sustainable pest management and rice health, particularly in Thailand. Together, these researchers continue to work towards the success of IPM and the sustainability of rice production. However, there is considerable scope for expanding research agendas to fill current knowledge gaps and develop workable solutions to emerging rice health syndromes as well as to improve current IPM practices and their levels of adoption.

\section{References}

Abdollahzadeh, G., Sharifzadeh, M. S. and Damalas, C. A. 2015. Perceptions of the beneficial and harmful effects of pesticides among Iranian rice farmers influence the adoption of biological control. Crop Protection, 75, 124-31.

Adalla, C. B., Magsino, E. A., Joshi, R. and Sebastian, L. 2006. Understanding the golden apple snail (Pomacea canaliculata): biology and early initiatives to control the pest in the Philippines. In Joshi, R. C. and Sebastian, L. S. (eds), Global Advances in Ecology and Management of Golden Apple Snails, PhilRice, Nueva Ecija, Philippines, pp. 199-213.

Agarrwal, R., Bentur, J. S. and Nair, S. 2014. Gas chromatography mass spectrometry based metabolic profiling reveals biomarkers involved in rice-gall midge interactions. Journal of Integrative Plant Biology, 56, 837-48.

Ampong-Nyarko, K. and Datta, S. K. 1993. Effects of nitrogen application on growth, nitrogen use efficiency and rice-weed interaction. Weed Research, 33, 269-76.

Avery, M. L., Decker, D. G., Humphrey, J. S. and Laukert, C. C. 1996. Mint plant derivatives as blackbird feeding deterrents. Crop Protection, 15, 461-4.

Avery, M. L., Humphrey, J. S., Decker, D. G. and McGrane, A. P. 1999. Seed color avoidance by captive red-winged blackbirds and boat-tailed grackles. The Journal of Wildlife Management, 1003-8.

Avery, M. L., Werner, S. J., Cummings, J. L., Humphrey, J. S., Milleson, M. P., Carlson, J. C., Primus, T. M. and Goodall, M. J. 2005. Caffeine for reducing bird damage to newly seeded rice. Crop Protection, 24, 651-7.

Azzam, O. and Chancellor, T. C. B. 2002. The biology, epidemiology, and management of rice tungro disease in Asia. Plant Disease, 86, 88-100. 
Azzam, S., Wang, F., Wu, J.-C., Shen, J., Wang, L.-P., Yang, G.-Q. and Guo, Y.-R. 2009. Comparisons of stimulatory effects of a series of concentrations of four insecticides on reproduction in the rice brown planthopper Nilaparvata lugens Stål (Homoptera: Delphacidae). International Journal of Pest Management, 55, 347-58.

Balasubramanian, V., Sie, M., Hijmans, R. J. and Otsuka, K. 2007. Increasing rice production in subSaharan Africa: challenges and opportunities. Advances in Agronomy, 94, 55-133.

Bandara, R. and Tisdell, C. 2002. Asian elephants as agicultural pests: Economics of control and compensation in Sri Lanka. Natural Resources Journal, 42, 491-519.

Bandong, J. P., Canapi, B. L., Dela Cruz, C. G. and Litsinger, J. A. 2002. Insecticide decision protocols: a case study of untrained Filipino rice farmers. Crop Protection, 21, 803-16.

Bentley, J. W. 2009. Impact of IPM extension for smallholder farmers in the tropics. In Peshin, R. and Dhawan, A. K. (eds), Integrated Pest Management: Dissemination And Impact, Springer Science, pp. 333-46.

Berg, H. and Tam, N. T. 2012. Use of pesticides and attitude to pest management strategies among rice and rice-fish farmers in the Mekong Delta, Vietnam. International Journal of Pest Management, 58, 153-64.

Biswas, M., Parveen, S., Shimozawa, H. and Nakagoshi, N. 2005. Effects of Azolla species on weed emergence in a rice paddy ecosystem. Weed Biology and Management, 5, 176-83.

Blackshaw, R. E., Brandt, R. N., Janzen, H. H., Entz, T., Grant, C. A. and Derksen, D. A. 2003. Differential response of weed species to added nitrogen. Weed Science, 51, 532-9.

Blengini, G. A. and Busto, M. 2009. The life cycle of rice: LCA of alternative agri-food chain management systems in Vercelli (Italy). Journal of Environmental Management, 90, 1512-22.

Bolwig, S., Ponte, S., Du Toit, A., Riisgaard, L. and Halberg, N. 2010. Integrating poverty and environmental concerns into value-chain analysis: a conceptual framework. Development Policy Review, 28, 173-94.

Bommarco, R., Kleijn, D. and Potts, S. G. 2013. Ecological intensification: harnessing ecosystem services for food security. Trends in Ecology and Evolution, 28, 230-8.

Bottrell, D. G. and Schoenly, K. G. 2012. Resurrecting the ghost of green revolutions past: The brown planthopper as a recurring threat to high-yielding rice production in tropical Asia. Journal of Asia-Pacific Entomology, 15, 122-40.

Brown, J. K. M. 2002. Yield penalties of disease resistance in crops. Current Opinion in Plant Biology, $5,339-44$.

Cai, Z., Xing, G., Yan, X., Xu, H., Tsuruta, H., Yagi, K. and Minami, K. 1997. Methane and nitrous oxide emissions from rice paddy fields as affected by nitrogen fertilisers and water management. Plant and Soil, 196, 7-14.

Catling, D. 1992. Rice in Deep Water, Macmillan Press, London, UK.

Chauhan, B. S. 2012. Weed ecology and weed management strategies for dry-seeded rice in Asia. Weed Technology, 26, 1-13.

Chauhan, B. S., Singh, R. G. and Mahajan, G. 2012. Ecology and management of weeds under conservation agriculture: a review. Crop Protection, 38, 57-65.

Chen, H., Stout, M. J., Qian, Q. and Chen, F. 2012. Genetic, molecular and genomic basis of rice defense against insects. Critical Reviews in Plant Sciences, 31, 74-91.

Chen, L. J., Lee, D. S., Song, Z. P., Suh, H. S. and Lu, B. R. 2004. Gene flow from cultivated rice (Oryza sativa) to its weedy and wild relatives. Annals of Botany, 93, 67-73.

Cheng, J. 2009. Rice planthopper problems and relevant causes in China. In Heong, K. L. and Hardy, B. (eds), Planthoppers: New Threats to the Sustainability of Intensive Rice Production Systems in Asia, International Rice Research Institute, Philippines, pp. 157-78.

Chin, D. V. 2001. Biology and management of barnyardgrass, red sprangletop and weedy rice. Weed Biology and Management, 1, 37-41.

Chintalapati, P., Katti, G., Puskur, R. R. and Nagella Venkata, K. 2016. Neonicotinoid-induced resurgence of rice leaffolder, Cnaphalocrocis medinalis (Guénee). Pest Management Science, $72,155-61$. 
Cockfield, G., Mushtaq, S. and White, N. 2012. Relocation of Intensive Agriculture to Northern Australia: The Case of the Rice Industry. Technical Report, University of Southern Queensland, Toowoomba, Australia.

Commare, R. R., Nandakumar, R., Kandan, A., Suresh, S., Bharathi, M., Raguchander, T. and Samiyappan, R. 2002. Pseudomonas fluorescens based bio-formulation for the management of sheath blight disease and leaffolder insect in rice. Crop Protection, 21, 671-7.

Culliney, T. W. 2005. Benefits of classical biological control for managing invasive plants. Critical Reviews in Plant Sciences, 24, 131-50.

De Koninck, R., Bernard, S. and Bissonette, J.-F. 2011. Borneo Transformed: Agricultural Expansion on the Southeast Asian Frontier, NUS Press, Singapore.

Dela Cruz, C. G. and Litsinger, J. 1988. Insect pests and their natural enemies in ratoon rice. In International Rice Research Institute (ed.), Rice rationing, International Rice Research Institute, Manila, Philippines, pp. 195-208.

Drost, D. C. and Moody, K. 1982. Rat damage in weed control experiments in rainfed transplanted rice. International Journal of Pest Management, 28, 295-9.

Dubey, N. K, Shukla, R., Kumar, A., Singh, P. and Prakash, B. 2010. Prospects of botanical pesticides in sustainable agriculture. Current Science, 98, 479-80.

Eggum, B. O. and Juliano, B. O. 1973. Nitrogen balance in rats fed rice differing in protein content. Journal of the Science of Food and Agriculture, 24, 921-7.

Elphick, C. S. and Oring, L. W. 1998. Winter management of Californian rice fields for waterbirds. Journal of Applied Ecology, 35, 95-108.

Food and Agriculture Organization of the United Nations. 2016. FAOSTAT [Online]. Available: http:// faostat3.fao.org/home/E [Accessed 30 June 2016].

Fujita, D., Kohli, A. and Horgan, F. G. 2013. Rice resistance to planthoppers and leafhoppers. Critical Reviews in Plant Sciences, 32, 162-91.

Gallagher, K. D., Kenmore, P. E. and Sogawa, K. 1994. Judicial use of insecticides deter planthopper outbreaks and extend the life of resistant varieties in Southeast Asian rice. In Denno, R. F. and Perfect, T. J. (eds), Planthoppers: Their ecology and Management, Springer-Science, pp. 299-614.

Godfray, H. C. J., Beddington, J. R., Crute, I. R., Haddad, L., Lawrence, D., Muir, J. F., Pretty, J., Robinson, S., Thomas, S. M. and Toulmin, C. 2010. Food security: The challenge of feeding 9 billion people. Science, 327, 812-18.

Gould, F. 1998. Sustainability of transgenic insecticidal cultivars: integrating pest genetics and ecology. Annual Review of Entomology, 43, 701-26.

Gravois, K. A. and Bernhardt, J. L. 2000. Heritability and genotype $\times$ environment interactions for discolored rice kernels. Crop Science, 40, 314-18.

Grecchi, R. C., Gwyn, Q. H. J., Bénié, G. B., Formaggio, A. R. and Fahl, F. C. 2014. Land use and land cover changes in the Brazilian Cerrado: A multidisciplinary approach to assess the impacts of agricultural expansion. Applied Geography, 55, 300-12.

Grigarick, A. A., Webster, R. K, Meyer, R. P, Zalom, F. G. and Smith, K. A. 1990. Effect of pesticide treatments on nontarget organisms in California rice paddies. I. Impact of triphenyltin hydroxide. II. Impact of diflubenzuron and triflumuron. Hilgardia, 58(1)

Grullón, G. 2013. Pesticide planet (Infographic). Science, 341, 730-1.

Guenha, R., Das Virtudes Salvador, B., Rickman, J., Goulao, L. F., Muocha, I. M. and Carvalho, M. O. 2014. Hermetic storage with plastic sealing to reduce insect infestation and secure paddy seed quality: A powerful strategy for rice farmers in Mozambique. Journal of Stored Products Research, 59, 275-81.

Gurr, G. M. 2009. Prospects for ecological engineering for planthoppers and other arthropods in rice In Heong, K. L. and Hardy, B. (eds), Planthoppers: New Threats To The Sustainability of Intensive Rice Production Systems in Asia, International Rice Research Institute, Philippines, pp. 371-88.

Gurr, G. M., Lu, Z., Zheng, X., Xu, H., Zhu, P., Chen, G., Yao, X., Cheng, J., Zhu, Z., Catindig, J. L., Villareal, S., Chien, H. V., Cuong, L. Q., Channoo, C., Chengwattana, N., Lan, L. P., Hai, L. H., Chaiwong, J., Nicol, H. I., Perovic, D. J., Wratten, S. D. and Heong, K. L. 2016. Multi-country 
evidence that crop diversification promotes ecological intensification of agriculture. Nature Plants, 2, 16014.

Hafeez, M. M., Bouman, B. A. M., Van de Giesen, N. and Vlek, P. 2007. Scale effects on water use and water productivity in a rice-based irrigation system (UPRIIS) in the Philippines. Agricultural Water Management, 92, 81-9.

Hardin, M. R., Benrey, B., Coll, M., Lamp, W. O., Roderick, G. K. and Barbosa, P. 1995. Arthropod pest resurgence: an overview of potential mechanisms. Crop Protection, 14, 3-18.

Heap, I. 2014. Global perspective of herbicide-resistant weeds. Pest Management Science, 70, 1306-15.

Heinrichs, E. A. 1994. Impact of insecticides on the resistance and resurgence of rice planthoppers. In Denno, R. F. and Perfect, T. J. (eds), Planthoppers: Their ecology and Management, SpringerScience, pp. 571-98.

Hinterhuber, A. 2002. Value chain orchestration in action and the case of the global agrochemical industry. Long Range Planning, 35, 615-35.

Holt, J., Chancellor, T. C. B., Reynolds, D. R. and Tiongco, E. R. 1996. Risk assessment for rice planthopper and tungro disease outbreaks. Crop Protection, 15, 359-68.

Horgan, F. G. 2012. Diversity and defence: Plant-herbivore interactions at multiple scales and trophic levels. In Gurr, G. M., Wratten, S. D., Snyder, W. E. and Read, D. M. Y. (eds), Biodiversity and Insect Pests: Key Issues for Sustainable Management, Wiley-Blackwell, Oxford, UK, pp. 241-58.

Horgan, F. G. 2017. Ecology and management of apple snails in rice. In Chauhan, B., Jabran, K. and Gulshan, M. (eds), Rice Production Worldwide, Springer, Berlin (in press).

Horgan, F. G. and Crisol, E. 2013. Hybrid rice and insect herbivores in Asia. Entomologia Experimentalis et Applicata, 148, 1-19.

Horgan, F. G., Crisol-Martínez, E., Almazan, M. L. P., Romena, A., Ramal, A. F, Ferrater, J. B. and Bernal, C.C. 2016a. Susceptibility and tolerance in hybrid and pure-line rice varieties to herbivore attack: biomass partitioning and resource-based compensation in response to damage. Annals of Applied Biology, 169, 200-13.

Horgan, F. G., Felix, M. I., Portalanza, D. E., Sánchez, L., Rios, W. M. M., Farah, S. E., Wither, J. A., Andrade, C. I. and Espin, E. B. 2014b. Responses by farmers to the apple snail invasion of Ecuador's rice fields and attitudes toward predatory snail kites. Crop Protection, 62, 135-43.

Horgan, F. G., Naik, B. S., Iswanto, E. H., Almazan, M. L. P., Ramal, A. F. and Bernal, C. C. 2016 c. Responses by the brown planthopper, Nilaparvata lugens, to conspecific density on resistant and susceptible rice varieties. Entomologia Experimentalis et Applicata, 158, 284-94.

Horgan, F. G., Ramal, A. F., Bentur, J. S., Kumar, R., Bhanu, K. V., Sarao, P. S., Iswanto, E. H., Chien, H. V., Phyu, M. H., Bernal, C. C., Almazan M. L. P., Alam, M. Z., Lu, Z. and Huang, S.-H. 2015. Virulence of brown planthopper (Nilaparvata lugens) populations from South and South East Asia against resistant rice varieties. Crop Protection, 78, 222-31.

Horgan, F. G., Ramal, A. F., Bernal, C. C., Villegas, J. M., Stuart, A. M. and Almazan, M. L. 2016 d. Applying ecological engineering for sustainable and resilient rice production systems. Procedia Food Science, 6, 7-15.

Horgan, F. G., Ramal, A. F., Villegas, J. M., Almazan, M. L. P., Bernal, C. C., Jamoralin, A., Pasang, J. M., Orboc, G., Agreda, V. and Arroyo, C. 2017b. Ecological engineering with high diversity vegetation patches enhances bird activity and ecosystem services in Philippine rice fields. Regional Environmental Change, (in press).

Horgan, F. G., Ramal, A. F., Villegas, J. M., Jamoralin, A., Bernal, C. C., Perez, M. O., Pasang, J. M., Naredo, A. I. and Almazan, M. L. P. 2017a. Effects of bund crops and insecticide treatments on arthropod diversity and herbivore regulation in tropical rice fields. Journal of Applied Entomology (in press).

Horgan, F. G., Srinivasan, T. S., Naik, B. S., Ramal, A. F., Bernal, C. C. and Almazan, M. L. P. 2016 b. Effects of nitrogen on egg-laying inhibition and ovicidal response in planthopper-resistant rice varieties. Crop Protection, 89, 223-30. 
Horgan, F. G., Stuart, A. M. and Kudavidanage, E. P. 2014a. Impact of invasive apple snails on the functioning and services of natural and managed wetlands. Acta Oecologica, 54, 90-100.

Horgan, F. G., Yanes Figueroa, J. and Almazan, M. L. P. 2014c. Seedling broadcasting as a potential method to reduce apple snail damage to rice. Crop Protection, 64, 168-76.

Hu, X.-F., Cheng, C., Luo, F., Chang, Y.-Y., Teng, Q., Men, D.-Y., Liu, L. and Yang, M.-Y. 2016. Effects of different fertilization practices on the incidence of rice pests and diseases: A three-year case study in Shanghai, in subtropical southeastern China. Field Crops Research, 196, 33-50.

Huan, N. H, Chien, H. V., Quynh, P. V., Tan, P. S., Du, P. V., Escalada, M. M. and Heong, K. L. 2008. Motivating rice farmers in the Mekong Delta to modify pest management and related practices through mass media. International Journal of Pest Management, 54, 339-46.

Huang, W.-K., Ji, H.-L., Gheysen, G., Debode, J. and Kyndt, T. 2015. Biochar-amended potting medium reduces the susceptibility of rice to root-knot nematode infections. BMC Plant Biology, $15,267$.

Inthavong, S., Schiller, J. M., Sengsoulivong, V. and Inthapanya, P. 2004. Status of gall midge in Lao PDR. In Bennett, J., Bentur, J. S., Pasalu, I. C. and Krishnaian, K. (eds), New Approaches To Gall Midge Resistance In Rice. International Rice Research Institute and Indian Council of Agricultural Research, pp. 77-87.

Ip, K. K. L., Liang, Y., Lin, L., Wu, H., Xue, J. and Qiu, J.-W. 2014. Biological control of invasive apple snails by two species of carp: Effects on non-target species matter. Biological Control, 71, $16-22$.

Ishii-Eiteman, M. J. and Power, A. G. 1997. Response of green rice leafhoppers to rice-planting practices in northern Thailand. Ecological Applications, 7, 194-208.

Isman, M. B. 2006. Botanical insecticides, deterrents, and repellents in modern agriculture and an increasingly regulated World. Annual Review of Entomology, 51, 45-66.

Jacob, J., Singleton, G. R., Herawati, N. A. and Brown, P. R. 2010. Ecologically based management of rodents in lowland irrigated rice fields in Indonesia. Wildlife Research, 37, 418-27.

Jagadish, S. V. K., Septiningsih, E. M., Kohli, A., Thomson, M. J., Ye, C., Redoña, E., Kumar, A., Gregorio, G. B., Wassmann, R., Ismail, A. M. and Singh, R. K. 2012. Genetic advances in adapting rice to a rapidly changing climate. Journal of Agronomy and Crop Science, 198, 360-73.

Jiang, M. X. and Cheng, J. A. 2003. Interactions between the striped stem borer Chilo suppressalis (Walk.)(Lep., Pyralidae) larvae and rice plants in response to nitrogen fertilization. Anzeiger für Schädlingskunde- Journal of Pest Science, 76, 124-8.

Kenmore, P. E., Carino, F. O., Perez, C. A., Dyck, V. A. and Gutierrez, A. P. 1984. Population regulation of the rice brown planthopper (Nilaparvata lugens Stål) within rice fields in the Philippines. Journal of Plant Protection in the Tropics, 1, 19-37.

Kiritani, K. 1999. Shift of IPM strategy for rice under global warming in temperate areas. In Zhongshan University (ed.), Integrated Pest Management In Rice-Based Ecosystem. Editorial Department, Journal of Zhongshan University, Guangzhou, China, pp. 235-44.

Ko, K., Liu, Y., Hou, M., Babendreier, D., Zhang, F. and Song, K. 2014. Evaluation for potential Trichogramma (Hymenoptera: Trichogrammatidae) strains for control of the striped stem borer (Lepidoptera: Crambidae) in the Greater Mekong Subregion. Journal of Economic Entomology, 107, 955-63.

Kojima, A., Yamashiro, C. and Arisaka, M. 1996. Regional control threshold of rice stem borer, Chilo suppressalis Walker (Lepidoptera: Pyralidae), indicated by adult catch with sex-pheromone trap. Japanese Journal of Applied Entomology and Zoology, 40, 279-86.

Kürschner, E., Hensche, C., Hildebrandt, T., Jülich, E., Leineweber, M. and Paul, C. 2010. Water saving in rice production-dissemination, adoption and short term impacts of alternate wetting and drying (AWD) in Bangladesh. Humboldt-Universitat Zu Berlin SLE Publication Series, S241.

Lamb, D. W. and Brown, R. B. 2001. PA - precision agriculture: Remote-sensing and mapping of weeds in crops. Journal of Agricultural Engineering Research, 78, 117-25.

Lane, S. J., Azuma, A. and Higuchi, H. 1998. Wildfowl damage to agriculture in Japan. Agriculture, Ecosystems and Environment, 70, 69-77. 
Laurance, W. F., Sayer, J. and Cassman, K. G. 2014. Agricultural expansion and its impacts on tropical nature. Trends in Ecology and Evolution, 29, 107-16.

Leach, M. C. and Hobbs, S. L. A. 2013. Plantwise knowledge bank: delivering plant health information to developing country users. Learned Publishing, 26, 180-5.

Lim, G. S. and Bottrell, D. G. 1994. Neem Pesticides in Rice: Potential and Limitations, International Rice Research Institute, Manila, Philippines.

Lin, W., Fang, C., Chen, T., Lin, R., Xiong, J. and Wang, H. 2010. Rice allelopathy and its properties of molecular ecology. Frontiers in Biology, 5, 255-62.

Litsinger, J. A., Barrion, A. T. and Soekarna, D. 1987. Upland rice insect pests: Their ecology, importance and control. IRRI Research Paper Series, 123. International Rice Research Institute, Manila, Philippines.

Liu, W.-Y., Wang, C.-Y., Wang, T.-S., Fellers, G. M., Lai, B.-C. and Kam, Y.-C. 2011. Impacts of the herbicide butachlor on the larvae of a paddy field breeding frog (Fejervarya limnocharis) in subtropical Taiwan. Ecotoxicology, 20, 377-84.

Loc, N. T. and Chi, V. T. B. 2005. Efficacy of some new isolates of Metarhizium anisopliae and Beauveria bassiana, against rice earhead bug, Leptocorisa acuta. Omonrice, 13, 69-75.

Matsumura, M. 2001. The current status of occurrence and forecasting system of rice planthoppers in Japan. Journal of Asia-Pacific Entomology, 4, 195-9.

Matsumura, M., Takeuchi, H., Satoh, M., Sanada-Morimura, S., Otuka, A., Watanabe, T. and Van Thanh, D. 2008. Species-specific insecticide resistance to imidacloprid and fipronil in the rice planthoppers Nilaparvata lugens and Sogatella furcifera in East and South-East Asia. Pest Management Science, 64, 1115-21.

Matsuno, Y., Nakamura, K., Masumoto, T., Matsui, H., Kato, T. and Sato, Y. 2006. Propspects for multifunctionality of paddy rice cultivation in Japan and other countries in monsoon Asia. Paddy Water Environment, 4, 189-97.

Matteson, P. C. 2000. Insect pest management in tropical Asian irrigated rice. Annual Review of Entomology, 45, 549-74.

Mattson, W. J. 1980. Herbivory in relation to plant nitrogen content. Annual Review of Ecology and Systematics, 11, 119-61.

Meyling, N. V. and Eilenberg, J. 2007. Ecology of the entomopathogenic fungi Beauveria bassiana and Metarhizium anisopliae in temperate agroecosystems: potential for conservation biological control. Biological Control, 43, 145-55.

Moody, K. and Drost, D. C. 1983. The role of cropping systems on weeds in rice. In International Rice Research Institute (ed.), Weed Control In Rice: Proceedings of The Conference on Weed Control In Rice, 1983. International Rice Research Institute, Los Baños, Philippines, pp. 73-86.

Morse, S. and Buhler, W. 1997. IPM in developing countries: the danger of an ideal. Integrated Pest Management Reviews, 2, 175-85.

Murdock, L. L. and Shade, R. E. 2002. Lectins and protease inhibitors as plant defenses against insects. Journal of Agricultural and Food Chemistry, 50, 6605-11.

Okuma, M., Fukushima, Y. and Tanaka, K. 1994. Feeding habits of apple snail (Pomacea canaliculata) to paddy weeds and damage avoidance to rice seedlings. Weed Research (Tokyo), 39, 109-13.

Padgham, J. L. and Sikora, R. A. 2007. Biological control potential and modes of action of Bacillus megaterium against Meloidogyne graminicola on rice. Crop Protection, 26, 971-7.

Palis, F. G. 1998. Changing farmers' perceptions and practices: the case of insect pest control in Central Luzon, Philippines. Crop Protection, 17, 599-607.

Parsa, S., Morse, S., Bonifacio, A., Chancellor, T.C.B, Condori, B., Crespo-Pérez, V., Hobbs, S.L.A, Kroschel, J., Ba, M. N., Rebaudo, F., Sherwood, S. G., Vanek, S. J., Faye, E., Herrera, M. A. and Dangles, O. 2014. Obstacles to integrated pest management adoption in developing countries. Proceedings of the National Academy of Sciences, 111, 3889-94.

Pathak, M. D. and Khan, Z. R. 1994. Insect Pests of Rice. International Rice Research Institute, Manila, Philippines. 
Patil, J., Miller, A. J. and Gaur, H. S. 2013. Effect of nitrogen supply form on the invasion of rice roots by the root-knot nematode, Meloidogyne graminicola. Nematology, 15, 483-92.

Pawlina, I. M. and Proulx, G. 1996. Study of house sparrow (Passer domesticus) feeding preference to natural color and guard coat blue coated seeds. Crop Protection, 15, 143-6.

Phelps, J., Carrasco, L. R., Webb, E. L., Koh, L. P. and Pascual, U. 2013. Agricultural intensification escalates future conservation costs. Proceedings of the National Academy of Sciences, 110, 7601-6.

Phillips, T. W. and Throne, J. E. 2009. Biorational approaches to managing stored-product insects. Annual Review of Entomology, 55, 375.

Phuong, L.T ., Denich, M., Vlek, P.L.G. and Balasubramanian, V. 2005. Suppressing weeds in directseeded lowland rice: Effects of methods and rates of seeding. Journal of Agronomy and Crop Science, 191, 185-94.

Pingali, P. L. 2001. Environmental consequences of agricultural commercialization in Asia. Environment and Development Economics, 6, 483-502.

Pingali, P. L. and Gerpacio, R. V. 1997. Living with reduced insecticide use for tropical rice in Asia. Food Policy, 22, 107-18.

Pingali, P. L. and Gerpacio, R. V. 1998. Toward reduced pesticide use for cereal crops in Asia. In Lutz, E., Binswanger, H., Hazell, P. and McCalla, A. (eds), Agriculture and the Environment: Perspectives on Sustainable Rural Development. Washington, DC, World Bank, pp. 254-70.

Pingali, P. L. and Roger, P. A. 1995. Impact of Pesticides on Farmer Health and the Rice Environment. International Rice Research Institute, Manila, Philippines.

Powles, S. B. and Shaner, D. L. 2001. Herbicide Resistance and World Grains, CRC Press.

Prasad, R. 2011. Aerobic rice systems. Advances in Agronomy, 111, 207-47.

Price, P. W. 1991. The plant vigor hypothesis and herbivore attack. Oikos, 244-51.

Prot, J.-C., Soriano, I. R. S. and Matias, D. M. 1994. Major root-parasitic nematodes associated with irrigated rice in the Philippines. Fundamental and Applied Nematology, 17, 75-8.

Pu, D., Shi, M., WuU, Q., Gao, M., Liu, J. F., Rer, S, Yang, F., Tang, P., Ye, G., Shen, Z., He, J., Yang, D., Bu, W., Zhang, C., Song, Q., Xu, D., Strand, M. R. and Chen, X. 2014. Flower-visiting insects and their potential impact on transgene flow in rice. Journal of Applied Ecology, 51, 1357-65.

Pucher, J., Steinbronn, S., Mayrhofer, R., Schad, I., El-Matbouli, M. and Focken, U. 2013. Improved sustainable aquaculture systems for small-scale farmers in northern Vietnam. In Fröhlich, H. L., Schreinemachers, P., Stahr, K. and Clemens, G. (eds), Sustainable Land Use and Rural Development in Southeast Asia: Innovations and Policies for Mountainous Areas, Springer, pp. 281-317.

Qiao, F., Huang, J., Zhang, L. and Rozelle, S. 2012. Pesticide use and farmers' health in China's rice production. China Agricultural Economic Review, 4, 468-84.

Rana, S. and Jain, D. 2013. Impact of modern agricultural practices on population density of Indian peafowl (Pavo cristatus) in Haryana, India. Agricultural Science Digest, 33, $230-3$.

Ranasinghe, L. L. 2003. Evaluation of factors responsible for low efficacy of farmer's weed management practices in rice cultivation. Annals of Sri Lanka Department of Agriculture, 5, 199-205.

Reddy, C. S., Laha, G. S., Prasad, M. S., Krishnaveni, D., Castilla, N. P., Nelson, A. and Savary, S. 2011. Characterizing multiple linkages between individual diseases, crop health syndromes, germplasm deployment, and rice production situations in India. Field Crops Research, 120, 241-53.

Rejesus, R. M., Mutuc, M. E. M., Yasar, M., Lapitan, A. V., Palis, F. G. and Chi, T. T. N. 2012. Sending Vietnamese rice farmers back to school: Further evidence on the impacts of farmer field schools. Canadian Journal of Agricultural Economics/Revue Canadienne d'Agroeconomie, 60, 407-26.

Rispail, N., Dita, M. A., González-Verdejo, C., Pérez-de-Luque, A., Castillejo, M. A., Prats, E., Román, B., Jorrín, J. and Rubiales, D. 2007. Plant resistance to parasitic plants: molecular approaches to an old foe. New Phytologist, 173, 703-12.

Robinson, E. J. Z., Das, S. R. and Chancellor, T. B. C. 2007. Motivations behind farmers' pesticide use in Bangladesh rice farming. Agriculture and Human Values, 24, 323-32. 
Rodenburg, J., Demont, M., Sow, A. and Dieng, I. 2014. Bird, weed and interaction effects on yield of irrigated lowland rice. Crop Protection, 66, 46-52.

Saka, M. 2010. Acute toxicity of rice paddy herbicides simetryn, mefenacet, and thiobencarb to Silurana tropicalis tadpoles. Ecotoxicology and Environmental Safety, 73, 1165-9.

Salim, M. and Saxena, R. C. 1991. Nutritional stresses and varietal resistance in rice: effects on whitebacked planthopper. Crop Science, 31, 797-805.

Santiapillai, C. and Read, B. 2010. Would masking the smell of ripening paddy-fields help mitigate human-elephant conflict in Sri Lanka? Oryx, 44, 509-11.

Sarangi, S. K., Singh, R. A. nd Singh, K. A. 2009. Indigenous method of rat proof grain storage by Adi tribes of Arunachal Pradesh. Indian Journal of Traditional Knowledge, 8, 230-3.

Savary, S., Castilla, N. P., Elazegui, F. A. and Teng, P. S. 2005. Multiple effects of two drivers of agricultural change, labour shortage and water scarcity, on rice pest profiles in tropical Asia. Field Crops Research, 91, 263-71.

Sexsmith, J. J. and Pittman, U. J. 1963. Effect of nitrogen fertilizers on germination and stand of wild oats. Weeds, 11, 99-101.

Sogawa, K., Liu, G. J. and Shen, J. H. 2003. A review on the hyper-susceptibility of Chinese hybrid rice to insect pests. Chinese Journal of Rice Science, 17, 23-30.

Spangenberg, J. H., Douguet, J.-M., Settele, J. and Heong, K. L. 2015. Escaping the lock-in of continuous insecticide spraying in rice: Developing an integrated ecological and socio-political DPSIR analysis. Ecological Modelling, 295, 188-95.

Stafford, J. D., Kaminski, R. M. and Reinecke, K. J. 2010. Avian foods, foraging and habitat conservation in world rice fields. Waterbirds, 33, 133-50.

Stewart, W. M., Dibb, D. W., Johnston, A. E. and Smyth, T. J. 2005. The contribution of commercial fertilizer nutrients to food production. Agronomy Journal, 97, 1-6.

Stuart, A. M., Palenzuela, A. N., Bernal, C. C., Ramal, A. F. and Horgan, F. G. 2014. Effects of fertiliser applications on survival and recruitment of the apple snail, Pomacea canaliculata (Lamarck). Crop Protection, 64, 78-87.

Sudianto, E., Beng-Kah, S., Ting-Xiang, N., Saldain, N. E., Scott, R. C. and Burgos, N. R. 2013. Clearfield $₫$ rice: Its development, success, and key challenges on a global perspective. Crop Protection, 49, 40-51.

Suding, K. N., Lejeune, K. D. and Seastedt, T. R. 2004. Competitive impacts and responses of an invasive weed: dependencies on nitrogen and phosphorus availability. Oecologia, 141, 526-35.

Settle, W. H., Ariawan, H., Astuti, E. T., Cahyana, W., Hakim, A. L., Hindayana, D. and Lestari, A. S. 1996. Managing tropical rice pests through conservation of generalist natural enemies and alternative prey. Ecology, 77, 1975-88.

Takahashi, K. and Otsuka, K. 2009. The increasing importance of nonfarm income and the changing use of labor and capital in rice farming: the case of Central Luzon, 1979-2003. Agricultural Economics, 40, 231-42.

Takamura, K. and Yasuno, M. 1986. Effects of pesticide application on chironomid larvae and ostracods in rice fields. Applied Entomology and Zoology, 21, 370-6.

Tanaka, K., Endo, S. and Kazano, H. 2000. Toxicity of insecticides to predators of rice planthoppers: Spiders, the mirid bug and the dryinid wasp. Applied Entomology and Zoology, 35, 177-87.

Teetes, G. L. 1994. Adjusting crop management recommendations for insect-resistant crop varieties. Journal of Agricultural Entomology, 11, 191-200.

Teillard, F., Maia de Souza, D., Thoma, G., Gerber, P. J. and Finn, J. A. 2016. What does Life-Cycle Assessment of agricultural products need for more meaningful inclusion of biodiversity? Journal of Applied Ecology, 53, 1422-9.

Teng, P. S. and Savary, S. 1992. Implementing the systems approach in pest management. Agricultural Systems, 40, 237-64.

Teo, S. S. 2001. Evaluation of different duck varieties for the control of the golden apple snail (Pomacea canaliculata) in transplanted and direct seeded rice. Crop Protection, 20, 599-604. 
Thorburn, C. 2015. The rise and demise of integrated pest management in rice in Indonesia. Insects, 6, 381-408.

Timmer, C. P. 2005. Food security and economic growth: an Asian perspective. Asian-Pacific Economic Literature, 19, 1-17.

Tindall, K. V. and Stout, M. J. 2003. Use of common weeds of rice as hosts for the rice water weevil (Coleoptera: Curculionidae). Environmental Entomology, 32, 1227-33.

Van Groenigen, J. W., Burns, E. G., Eadie, J. M., Horwath, W. R. and Van Kessel, C. 2003. Effects of foraging waterfowl in winter flooded rice fields on weed stress and residue decomposition. Agriculture, Ecosystems and Environment, 95, 289-96.

Vu, Q., Quintana, R., Fujita, D., Bernal, C. C., Yasui, H., Medina, C. D. and Horgan, F. G. 2014. Responses and adaptation by Nephotettix virescens to monogenic and pyramided rice lines with Grh-resistance genes. Entomologia Experimentalis et Applicata, 150, 179-90.

Wang, A.-H., Wu, J.-C., Yu, Y.-S., Liu, J.-L., Yue, J.-F. and Wang, M.-Y. 2005. Selective insecticideinduced stimulation on fecundity and biochemical changes in Tryporyza incertulas (Lepidoptera: Pyralidae). Journal of Economic Entomology, 98, 1144-9.

Watanabe, T., Takeuchi, H., Ishizaki, M., Yasuda, T., Tachibana, S.-I., Sasaki, R., Nagano, K., OkutaniAkamatsu, Y. and Matsuki, N. 2009. Seasonal attraction of the rice bug, Leptocorisa chinensis Dallas (Heteroptera: Alydidae), to synthetic attractant. Applied Entomology and Zoology, 44, 155-64.

Westphal, C., Vidal, S., Horgan, F. G., Gurr, G. M., Escalada, M., Chien, H. V., Tscharntke, T., Heong, K. L. and Settele, J. 2015. Promoting multiple ecosystem services with flower strips and participatory approaches in rice production landscapes. Basic and Applied Ecology, 16, 681-9.

Widawsky, D., Rozelle, S., Jin, S. and Huang, J. 1998. Pesticide productivity, host-plant resistance and productivity in China. Agricultural Economics, 19, 203-17.

Wilson, B. E., Hardy, T. N., Beuzelin, J. M., Vanweelden, M. T., Reagan, T. E., Miller, R., Meaux, J., Stout, M. J. and Carlton, C. E. 2015. Expansion of the Mexican rice borer (Lepidoptera: Crambidae) into rice and sugarcane in Louisiana. Environmental Entomology, 44, 757-66.

Wilson, E. A., Leboeuf, E. A., Weaver, K. M. and Leblanc, D. J. 1989. Delayed seeding for reducing blackbird damage to sprouting rice in southwestern Louisiana. Wildlife Society Bulletin, 17, 165-71.

Witzgall, P., Kirsch, P. and Cork, A. 2010. Sex pheromones and their impact on pest management. Journal of Chemical Ecology, 36, 80-100.

Wu, J., Xu, J., Yuan, S., Liu, J., Jiang, Y. and Xu, J. 2001. Pesticide-induced susceptibility of rice to brown planthopper Nilaparvata lugens. Entomologia Experimentalis et Applicata, 100, 119-26.

Xin, Z., Yu, Z., Erb, M., Turlings, T. C. J., Wang, B., Qi, J., Liu, S. and Lou, Y. 2012. The broad-leaf herbicide 2, 4-dichlorophenoxyacetic acid turns rice into a living trap for a major insect pest and a parasitic wasp. New Phytologist, 194, 498-510.

Yanes Figueroa, J., Almazan, M. L. P., Horgan, F. G. 2014. Reducing seed-densities in rice seedbeds improves the cultural control of apple snail damage. Crop Protection, 62, 23-31.

Yang, C. -M., Cheng, C. -H. and Chen, R. -K. 2007. Changes in spectral characteristics of rice canopy infested with brown planthopper and leaffolder. Crop Science, 47, 329-35.

Yoneyama, K., Xie, X., Yoneyama, K. and Takeuchi, Y. 2009. Strigolactones: structures and biological activities. Pest Management Science, 65, 467-70. 